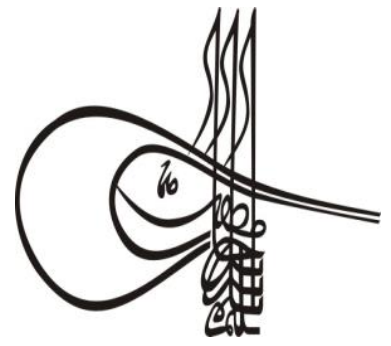

\begin{abstract}
Research Article / Araştırma Makalesi
Article Info/Makale Bilgisi
\end{abstract}

Skopje/MACEDONIA-Ankara/TURKEY

Volume 14 Issue 6, 2019, p. 3063-3087

DOI: 10.29228/TurkishStudies.30239

ISSN: 2667-5609

research Aricle/ Arastima Makalesi

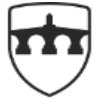

INTERNATIONAL BALKAN UNIVERSITY

EXCELLENCE FOR THE FUTURE IBU.EDU.MK

Received/Geliş: 16.08.2019

\Accepted/Kabul: 20.12.2019

This article was checked by iThenticate.

\title{
T.C. İNKILAP TARİHİ VE ATATÜRKÇÜLÜK ÖĞRETİMİNDE KANIT VE KAYNAK KULLANIMININ TARIHSEL ANLATILARA YANSIMALARININ İNCELENMESİ
}

\author{
Sezgin ELBAY*
}

\begin{abstract}
öz
Kanıt ve kaynaklar, tarihsel konuların öğretiminde işe koşulmaktadır. Bu konuda yapılan çalışmalar incelendiğinde, kanıt ve kaynakların tarih öğretimi bakımından, birçok yararının olduğu saptanmıștır. Öte yandan kanıt ve kaynakların tarihsel anlatılara yansımalarının ne olabileceğine yönelik yapılan çalışmalar azdır. Bununla birlikte, kanıt ve kaynak kullanımının, tarihsel anlatı seviyelerini nasıl etkilediği de ortaya çıkarılamamıştır. Bu bağlamda araştırmanın amacı, T.C. İnkılap Tarihi ve Atatürkçülük öğretiminde, kanıt ve kaynak kullanımının, tarihsel anlatılara ve tarihsel anlatı seviyelerine nasıl yansıdığını betimlemektir. Bunun için nitel araştırma yönteminin, durum çalışması yaklaşımından yararlanılmıştır. Araştırmaya, Sakarya kentinin kırsal bir bölgesinde yer alan, MEB'e bağlı resmi bir ortaokulun, 8. sınıfindaki 14 öğrenci (9 kız, 5 erkek) katılmıştır. Katılımcilar, ölçüt durum örnekleme yöntemine uygun olarak belirlenmiştir. Bu bağlamda katılımcılar, daha önce kanıt ve kaynaklarla çalışma deneyimi olmayan öğrenciler arasından seçilmiştir. Veriler, 2018/2019 eğitim-öğretim yılının, 1. döneminde toplanmıștır. Veri toplama araçları olarak; kişisel bilgi formu, katılımlı gözlem, grup tartışma notları ve dokümanlar kullanılmıştır. Toplanan veriler üzerinde, tümevarımsal ve betimsel analiz yapılmıştır. Verilerin analizi sonucunda, kanıt ve kaynak kullanımının, tarihsel bilgiyi kazandırma ve düşünmeyi geliştirme açısından çeşitli yansımalarının olduğu tespit edilmiştir. Aynı zamanda, anlatıların; $1 ., 2$. ve 3 . seviyeden anlatılara işaret ettiği saptanmıştır. Sonuç olarak, öğrencilerin, kanıt ve kaynakları, anlatılarını
\end{abstract}


desteklemek ve diğer görüşleri çürütmek amacıyla kullandıkları söylenebilir.

Anahtar Kelimeler: T.C. İnkılap Tarihi ve Atatürkçülük Öğretimi, Kanıt ve Kaynak Kullanımı, Tarihsel Anlatılar, Tarihsel Anlatı Seviyeleri.

\title{
INVESTIGATION OF THE REFLECTIONS OF THE USE OF EVIDENCE AND RESOURCES TO HISTORICAL NARRATIVES IN THE REVOLUTION HISTORY AND KEMALISM TEACHING
}

\begin{abstract}
Evidence and resources are serviced to teach historical subjects. When the studies on this subject are examined, it has been found that the evidence and resources have many benefits in terms of history teaching. On the other hand, there are few studies on the reflections of evidence and sources on historical narratives. However, it has not been established how evidence and resource use affect historical narrative levels. In this context, the aim of the research is to describe how the use of evidence and resources is reflected in historical narratives and historical narrative levels in the T.C. Revolution History and Kemalism teaching. For this purpose, case study approach of qualitative research method was used. 14 students (9 girls, 5 boys) from 8th grade of a secondary school affiliated to MEB, located in a rural area of Sakarya, participated in the study. The criteria of the participants were determined according to the situation sampling method. In this context, participants were selected from students who had no previous experience of working with evidence and resources. Data were collected in the first semester of $2018 / 2019$ academic year. Personal information form, participatory observation, group discussion notes and documents were used as data collection tools. Inductive and descriptive analyzes were performed on the collected data. As a result of the analysis of the data, it has been determined that the use of evidence and resources has various reflections in terms of gaining historical knowledge and improving thinking. It was also found that the narratives refer to the narratives of levels 1,2 and 3 . As a result, it can be said that students use evidence and resources to support their narratives and refute other opinions.
\end{abstract}

\section{STRUCTURED ABSTRACT}

Evidence and resources can be used with different approaches. One of these approaches may be historical narratives. Because students can take into account the feelings and thoughts of historical representatives at the same time when they write. (De Leur, Boxtel and Wilschut, 2017).

Historical narratives can be evaluated using Shelmit's (2000) theoretical framework. In this context, Shelmit (2000) has set 4 levels for narratives. These include: 1 . level is chronological narrative, 2 . level is consistent historical narrative, 3 . level is multidimensional narrative and 4. level is polytechnic narratives. 
Previous studies on the use of evidence and resources have focused on several different issues. Some studies have reported the positive effects of evidence and resource use on historical thinking (Ayva, 2012; Bilgiç, 2018; Bozkurt, 2018; Iș1k, 2011; Özbaș, 2010; Stradling, 2003; Vella, 2009). Some studies also found that evidence and resource use had a significant effect on academic achievement (Akbaba, 2005; Bakmaz, 2016; Keless et al., 2006; Kız1l, 2018; Namal 2011; Tangülü and Çıdaç1, 2016).

As a result, there is no study in the literature that reflects the evidence and sources on historical narratives written from third parties and determines the levels of these narratives. In this context, the reflections of the evidence and sources to the historical narratives written from the third party and the levels of these narratives can be revealed by using a qualitative research approach and involving students as a researcher. Thus, researchers can develop different approaches to historical narratives. Program development experts can design patterns and teachers can make lesson plans accordingly. In this context, the aim of the research is to reveal the reflections of the evidence and sources on the historical narratives and to describe the narrative levels of the students.

The research was conducted in accordance with the case study approach, which is one of the qualitative research methods. The design of the research is the only holistic case design. In this context, the process of using evidence and resources, its holistic situation and its reflections on historical narrative and historical narrative levels constituted its two subunits.

Participants consisted of students in the 8th grade of a secondary school affiliated to MEB (Ministry of Education) in a rural area of Sakarya. The research was conducted in the first semester of 2018/2019 academic year. A total of 14 students, 9 girls and 5 boys, participated in the study. The students were selected according to the criteria status sampling method. In this context, students who had no previous experience of working with evidence and resources were included in the study.

Video recorded group discussions, participatory observation and historical narratives were used as data collection tools. Group discussions have had the benefit of assessing the physical and psychological responses of students using evidence and resources, and checking whether their oral and written expression matches. Participatory observation was needed to record the movements of the students who read their writings and defended their thoughts as a whole. With these; the historical narratives of students, how they reflect the elements such as "historical representative, language, point of view and prejudice" (Yeager et al., 1998: 20) in the evidence and sources are determined.

In accordance with the first aim of the study, the data were subjected to inductive analysis. For this purpose, the data was first coded line by line, and then the codes were reduced to certain categories. At the last stage, the main themes have been reached. In accordance with the second aim of the study, descriptive analysis was performed. For this purpose, the data were coded according to Shelmit's (2000) historical narrative levels. 
As a result of the data analysis, it was found that the use of evidence and resources had various reflections in terms of gaining historical knowledge and improving thinking. In this context, acquisition chronological and periodical knowledge under the theme of historical information acquisition, analyze historical inferences and historical conditions under the theme of historical contextualization, taking multiple perspectives derived from two perspectives under the theme of intent analysis and determining the role of historical actors, common concerns and nationalist discourses under the theme of contact with emotions and categories of sympathetic response and loss of identity under the theme of identification are grouped. In addition, it was found that narratives were constructed at levels 1, 2 and 3, whereas a narrative could not be constructed at level 4 .

When an overall assessment of the findings is made, a few conclusions may be drawn primarily from the research. Firstly, it is thought that the use of evidence positively affects students' historical thinking. Similarly, in many studies, evidence has been reported to provide these effects (Ayva, 2012; Bozkurt, 2018; Iş1k, 2011; Patterson, Lucas and Kithinji, 2012; Torres, 2016). Second, the evidence is thought to cause different emotional reactions in students. In this context, students who examined the same evidence were able to show an emphatic or sympathetic response to historical representatives. However, according to Blake (1998), sympathy poses a barrier to empathy. Third, primary resource use contributed to students' historical inquiries. Similarly, Levstik and Barton (2011) stated that primary resource use is one of the most effective questioning tools in understanding historical events and helps to learn. In parallel, primary sources support students' practical skills in relation to historical inquiry (NCSS, 2013). Fourth, the students used evidence and resources to support their narratives and refute other opinions. Fifth, the most controversial finding in terms of its utility in history teaching is thought to be identification. It may be suggested to examine the reflections of evidence and resource use on historical narratives by quantitative methods based on the findings, to investigate how students can increase their narrative levels by using evidence and resources.

Keywords: T.R. Revolution History and Kemalism Teaching, Evidence and Use of Resources, Historical Narratives, Historical Narrative Levels.

\section{Giriş}

Tarih, geçmiş zamanlardaki olayları neden-sonuç ilişkisi içerisinde, kronolojik ve sistematik bir şekilde inceleyen bir bilim dalıdır (Sander, 2013). Bu bağlamda neden-sonuç ilişkisinin kurulması ve geçmişteki olayların yansımalarının değerlendirilmesinde, sistematik bir düşünme anlayışına sahip olmak gerekebilir. Sistematik düşünme anlayışı, kronolojinin yanı sıra, tarihsel olaylar üzerinde yorum yapmayı da içermektedir. Çünkü Barton ve Levstik' in (2004) ifade etmiş oldukları gibi, tarihçi yorum yapmaktan kaçınamaz. Ancak bu yorumlar, tarihsel bilgiye dayalı olarak yapilmalidir.

Geçmiş zamana ait bilgiler, çeşitli dersler aracıllğıyla öğrencilere aktarılmaya çalışılmaktadır. $\mathrm{Bu}$ derslerden biri de, ortaokul 8. sınıfta okutulan T.C. İnkılâp Tarihi ve 
Atatürkçülük dersidir. Okullarda bu ders 1925 yılından itibaren "İhtilaller Tarih dersi" adıyla verilmeye başlanmıştır.

Ortaokul 8. sınıf T.C. İnkılap Tarihi ve Atatürkçülük dersinde öncelikle öğrencilerin; Atatürk'ün askerlik ve devlet adamlığı rolünü ve inkılapçı özelliklerini öğrenerek; onun kişilik özelliklerini örnek almaları, Millî Mücadele örneğinden hareketle Türk milletinin millî birlik ve beraberlik anlayışı içerisinde özgürlük, bağımsızlık ve vatanseverlik duyguları ile her türlü zorluğun üstesinden gelebileceğini anlamaları, Türk Millî Mücadelesi ve İnkılabının, millî ve evrensel özelliklerini kavramaları amaçlanmaktadır (MEB, 2018). Ayrıca bu dersi veren öğretmenlerden, T.C. İnkılap Tarihi ve Atatürkçülük dersinde geçen kavramları (kanıt, neden-sonuç, değişim-süreklilik, benzerlik-farklılık gibi), öğrencilerine öğretmeleri ve bu kavramları öğrencilerin doğru kullanmalarına çalışmaları beklenmektedir. Bununla birlikte öğretmenler, tarihsel düşünme becerilerini geliştirmek için, farklı yöntem ve teknikler işe koşabilmelidirler. Aynı zamanda konular işlenirken, birinci el kaynakların (arşiv belgeleri, somut tarihî miras ögeleri, Nutuk vb.) kullanılması ve öğrencilerin, ele alınan olayları tarihsel bağlama göre kavrayabilmeleri için, o dönemle ilgili yazıl1, sesli, görsel ve görüntülü kaynakları incelemeleri gerekmektedir (MEB, 2018).

\subsection{Tarihsel Kanit ve Kaynaklar}

Tarihsel kanıt ve kaynaklar incelendiğinde, birtakım sorular akla gelebilir. Bu bağlamda ''Doğru bilgiye ulaştıracak kanıt ve kaynaklar var mıdır?' ve "'Kanıt ve kaynakların güvenilir ve geçerli bilgiler verdiğinden nasıl emin olunabilir?' gibi sorular, tarihsel kanıtlarla ilgili bir tartışmaya da neden olmaktadır. Carr (1996), kanıtların, geçmișe ait olduğunu belirterek, kanıtları var olan ve bir yorumu desteklemek amacıyla kullanılan işaretler olarak tanımlamaktadır. Bu bağlamda kanıtların, geçmişten izler taşıdığı ve geçmiş olayları değerlendirebilmek için, işe koşulabileceği söylenebilir. Bununla ilgili olarak Collingwood (1996: 92), kanttların değerlendirilmesinde, tarihsel bilginin şart olduğunu savunmuştur. Ona göre, tarihsel bilgideki artış ile kanıtı tanıma ve onu değerlendirme becerisi arasında bir ilişki bulunmaktadır. Öte yandan bilgideki bu artış, tarihsel kanıtları yorumlama ve anlamlandırmayı da etkileyebilir. Buna paralel olarak Husbans (1996), geçmişin kalıntı ve izlerinin, günümüze tarihsel kanıtlarla yansıdığını ve bu kanıtların, bireyin kendi bilişsel şemasına uygun olarak sorgulandıktan sonra anlam kazandığını ifade etmektedir. Ancak kanıt ve yorum arasındaki bu ilişki, postmodern tarihçiler tarafindan eleştirilmektedir. Bu bağlamda Jenkins (1997), geçmiş sona erse de, geçmişin izlerinin süreceğini ileri sürmüştür. Öte yandan bu izler, tarihçinin onları bulup-bulmamasına göre değişmemektedir. Bununla bağlantı olarak kanıtlar, yorum ve savları desteklemek için, araçsallaştırılarak kullanılmaktadır. Yani Jenkins, kanıtların, yorumlardan sonra arandığını savunmuștur. O halde tarih ve geçmiş farklıdır. Bu yüzden tarihsel yorumların hangi kaynaklara dayandırıldığının bilinmesi gerekebilir. Ardından ders kitaplarındaki mevcut durum incelenebilir.

MEB'in ortaokul 8. sınıflar için hazırladığı T.C. İnkılap Tarihi ve Atatürkçülük ders kitabında (2018), kaynakların kanıt olarak kullanıldığı saptanmıştır. Bu kitabın; okuma parçaları, sorular, sanat ve edebiyat eserleri gibi bölümlerinde, kanıtların yer aldığı belirlenmiştir. Kanıtların ders kitaplarında yer alması, tarihsel düşünmeye katk1 sağlayabilir. Ancak bu, kanıtları sadece okumak ve kanıtlar üzerinde analiz yapmayı gerektirmeyen birkaç soru sormakla sağlanamayabilir. Oysaki tarihsel malzemelerin, bir tarihçi gibi öğrenciler tarafindan kullanılması gerekmektedir. Bu süreçte, öğrenciler görüşlerini geliştirmek, düşüncelerini savunmak ve temellendirmek için, tarihsel kanıtlara gereksinim duyabilirler. Öğretmen de süreç esnasında, öğrenme ve öğretmenin ilkelerine uygun olarak rehber olabilir.

Kanıtlar, beynin iki yarım küresini harekete geçirecek şekilde kullanılmalıdır. Çünkü böylece öğrenmeler daha kalıcı olabilir ve belli bir tarihsel olay çoklu perspektifler açısından incelenebilir. Bu bağlamda Paivio (1991), ikili kodlama kuramında, öğrenmenin, beynin iki yarım 
küresini etkin kılacak bir şekilde gerçekleşmesi durumunda, daha kalıcı olduğunu belirtmektedir (Paivio, 1991a; Paivio, 1991b). Bunun için öğrencilerin, görsel ve yazılı kaynakları, çeşitli etkinliklerle incelemeleri sağlanmalıdır. Böylece öğrenciler, kaynaklara soru sorarak kanıtları eleyebilir, sınıflandırabilir ve sonuçları sözlü, yazılı veya model yoluyla; resimlerle, dramayla sunabilirler (Cooper, 1996: 76; Mims, 2002: 143-144; Köksal, 2005: 73). Sonuç olarak öğrenciler, bir tarihçi gibi düşünmeye başlayabilirler. Öte yandan bir tarihçi gibi düşünmeye başladıktan sonra öğrencilere, ek görevler verilebilir.

\subsection{Tarihsel Anlatılar}

Tarihsel kaynakların kanıt olarak kullanılmasında farklı yaklaşımlar benimsenebilir. $\mathrm{Bu}$ yaklaşımlardan biri, tarihsel anlatılar olabilir. Çünkü öğrenciler yazarken, tarihsel temsilcilerin duygu ve düşüncelerini aynı anda göz önünde bulundurabilirler (De Leur, Boxtel ve Wilschut, 2017). Ayrıca öğrencilerin, tarihsel anlatılar inşaa ederken, düşüncelerini desteklemek için, kanıtlar kulland1kları tespit edilmiştir (Brooks, 2008; De Leur ve diğerleri 2017). Bununla birlikte anlatılar, tarihsel temsilcilerin perspektiflerini, kanıtlara dayanarak yeniden almaya da olanak sağlamaktadır (Harris ve Foreman-Peck, 2004).

Tarihsel anlatılar inşaa edilirken, şahıs ekleri, öncelikli olarak göz önünde bulundurulmalıdır. Çünkü yapılan çalışmalarda; birinci ve üçüncü tekil şahıs ekleriyle ve edilgen çatıyla olgusal bir şekilde yazılan anlatılar arasında farklılıklar tespit edilmiştir (Brooks, 2008; De Leur ve diğerleri 2017). Buna paralel olarak Ruby ve Decety (2004), kendisi (birinci tekil şahıs anlatımı) veya başka bir kişi hakkında düşünen (üçüncü tekil şahıs anlatımı) bireyler arasında, nörolojik olarak farklılıklar bulunabileceğini saptamışlardır. Bununla birlikte onlar, başka bir kişinin perspektifinin alınabilmesi için, kişinin kendi perspektifini düzenleyebilmesi gerektiğini savunmuşlardır. Başka bir deyişle, bir kişi başka birinin perspektifini almak için, kendi perspektifini paranteze alabilmelidir. $\mathrm{Bu}$ araştırmada öğrencilerden, geçmişte kendilerini üçüncü kişilerin yerine koyarak anlatılarını inşaa etmeleri istenmiş olmasına rağmen, öğrencilerin birinci tekil şahıs anlatımıyla ve olgusal anlatımla da yazdıkları görülmüş̧ür.

Anlatıların öğretimi ve değerlendirilmesinde, Shemilt'in (2000), teorik çerçevesinden yararlanılabilir. Bu konuda Shemilt (2000), tarihsel anlatıların değerlendirilmesinde, dört seviye belirlemiştir. Anlatılara yönelik seviyeler tablo 1'de sunulmuştur: 
Tablo 1: Shelmit'in (2000) Tarihsel Anlatı Seviyeleri ve Örnek Anlatılar

Anlatı Seviyesi

1. Kronolojik Anlatı

Tanım

Örnek Anlatı

Tarihsel olaylar, belli bir Atatürk, 19 Mayıs 1919'da Samsun'a öncelik-sonralık sırası gitmiştir. Ardından 28 Mayıs 1919'da gözetilerek yazılır.

Havza ve 22 Haziran 1919'da Amasya

Genelgeleri'ni yayımlamış, 23 Temmuz-7

Ağustos 1919'da Erzurum, 4-11 Eylül 1919’da Sivas Kongreleri'ni düzenlemiştir.

2. Tutarlı Tarihsel Anlatılar

Tarihsel olaylardaki örüntü, İngiltere, Berlin Kongresi'ne kadar (1878), mantık çerçevesi içerisinde Osmanlı İmparatorluğu'nun toprak ve çelişkiye yer bütünlüğünden yana olmuştur. Ancak bu birakmayacak bir şekilde Kongreden sonra, Osmanlı ortaya konulur. Böylece İmparatorluğu'nun toprakları üzerinde tarihsel olaylardaki yeni küçük devletler kurma yoluna gitmiş ve katman ve boyutlar tutarlı bir başta Kıbrıs ve Mısır olmak üzere, Osmanlı şekilde açıklanır.

Yakındoğu'sunu kendi yönetmiştir. Çünkü Osmanlı, artık kendini koruyamamakta, diğer yandan Rusya da, Hindistan yolu için bir tehdit oluşturmaktadır.

3. Çok Boyutlu Anlatılar

Tarihsel olaylar birçok farklı Osmanlı İmparatorluğu'na, Tanzimat açıdan değerlendirilmeye Fermanı'nın, kültürel bir ivme kazandırdığg çalışılır. $\mathrm{Bu}$ bağlamda ileri sürülebilir. Çünkü o zamana kadar tarihsel bir anlatıda olayların, edebi ve siyasi içerikli yayınların ve tiyatro sosyo-politik ve psikolojik gibi Batı usulü sanatların yaygın olmadığ yanları bir bütün olarak bilinmektedir. $\mathrm{Bu}$ durum aynı zamanda, hesaba katılmaya başlanılır. Batı Aydınlanması'nın Osmanlı Aynı zamanda, toplumsal topraklarına girmesinin de bir göstergesi örgütlenme biçimleri olabilir. Diğer yandan kölelik usulünün hala (toplumsal yap1, kurum ve devam etmesi, Şeriat Kanunu'na dayanan politikalar), kültürel ve bir devlet yönetiminin varlığı, toplumsal entelektüel tarih (sağduyu, yapının laik ve rasyonel bir reform din, ekonomi ve hareketine çok da hazır olmadığını kurumsallaşmış bilgi) göz göstermektedir. önünde bulundurulur.

4. Politeknik Anlatı Çerçeveleri
$\mathrm{Bu}$ anlatılarda, çok çeşitli Türkiye neden NATO'ya üye oldu? Bu sanat ve bilim konuları sorunun birden çok yanıtı olabilir. işlenir. Bununla paralel Öncelikle Türkiye, 2. Dünya Savaşı'ndan olarak, örgütlenmiş ve sonra, Rusya'nın tehditlerine maruz sentezlenmiş bilgi sunulur. kalmıştır. $\mathrm{Bu}$ tehditleri, kendi gücüyle $\mathrm{Bu}$ tür anlatılarda, geçmiş önlemenin olanaksızlığını anlayınca, hakkında en olası açıklamalar NATO'ya üye olmak istemiştir. Öte yandan sunulmaya çalışılır. Böylece NATO, TSK'yi hiyerarşik örgütlenme büyük resim çeşitli bakış modelinin içerisine dâhil etmiş ve açılarından Türkiye'de üsler de kurmuştur. Bununla değerlendirilebilir. $\quad$ Bu paralel olarak Türkiye, kendisiyle ilgili seviyede kabul edilen olmayan bir savaş olan Kore'ye, NATO'ya anlatılar, karşıllaştırmalı bilgi girmenin önşartı olarak, asker göndermiştir. ve yorum içerir ve tarihsel Sonuç olarak Türkiye, bir yandan ABD'nin rölativizmi destekler. eksenine girerken, diğer yandan Rusya'nın tehdit sahasının dişına çıkmıştır. 
Tablo 1, tarihsel anlatıların heterarşik bir modelini ortaya koymaktadır. Bu bağlamda her anlat1, kendisinden önceki anlatıdan seviye olarak farklı olmaktadır. Bununla paralel olarak anlatıların hangi seviyeden olduğu analiz edilerek, öğrencilerin zamanın geçişlerini nasıl yönettikleri keşfedilebilir.

Öğrenciler, bir tarihçi gibi düşünmek için, tarihsel yorumların arka planındaki kanıtları ortaya çıkarmalı ve değerlendirmelidir (Grim, Pace ve Shopkow, 2004). Bununla koşut olarak MEB'in (2018) hazırladığı T.C. İnkılap Tarihi ve Atatürkçülük dersi öğretim programında, kanıtların analizi ve değerlendirilmesinin, tarihsel düşünme ve yorum için öncelikli olduğu vurgulanmaktadır. Öte yandan bu eğilimin öğrencilerde az olduğu, öğretmen görüşlerinden ortaya çıkarılmıştır (Tangülü, Tosun ve Kocabıyık, 2014). Bu eğilim tersine çevrilmezse, sonuç olarak öğrenciler tarihsel düşünme ve akıl yürütmeyi (historical reasoning), gerçekleştiremeyebilirler. Çünkü tarihsel akıl yürütme; kanıtı analiz etmeyi, kanıtın anlamını yorumlamayı, tarihsel tartışmalar yapmak ve tarihsel olayları açılamak için, uygun kanıtları işe koşmayı ve kanıtı kullanırken önyargıdan kaçınmayı içermektedir (Monte-Sano, 2006).

Kaynakların kanıt olarak kullanımıyla ile ilgili daha önce yapılan çalışmalar, birkaç farklı konuya odaklanmıştır. Bazı çalışmalar, tarihsel çalışmalarda kanıtların eksiksiz bir şekilde toplanmasını incelemiş ve kanıtların argümanlarla birlikte savunulması gerektiğini bildirmiştir (örneğin Grim ve diğerleri, 2004). Bazı çalışmalar, kaynak kullanımının tarihsel düşünme üzerindeki etkisine odaklanmıştır. Bu çalışmalar, kaynak ve kanıt kullanımının, tarihsel düşünmeye olumlu etkilerini rapor etmiştir (Ayva, 2012; Bilgiç, 2018; Bozkurt, 2018; Işık, 2011; Özbaş, 2010; Stradling, 2003; Vella, 2009). Bazı çalışmalar, kaynak kullanma ve akademik başarı arasındaki ilişkiyi incelemiş ve kaynak kullanmanın, akademik başarı üzerinde anlamlı bir etkisinin olduğunu saptamıştır (Akbaba, 2005; Bakmaz, 2016; Keleş ve diğerleri, 2006; Kızıl, 2018; Namal 2011; Tangülü ve Çıdaçı, 2016). Bazı çalışmalar, farklı perspektifler sunan kaynakların etkilerini incelemiş ve ögrencilerin tek kaynaktan yararlanma eğiliminde olduklarını belirlemiştir (örneğin Amaral, 2008). Bunun aksine bazı çalışmalar, çok çeşitli görsel materyal kullanmanın, çoklu perspektif almaya katkı sağladığını rapor etmiştir (Yahşi ve Keleş, 2013). Bu çalışmalardan anlaşılacağı gibi, kanıt ve kaynakların, çok çeşitli etkileri ortaya konulmuş olmasına rağmen, hiçbir çalışmada, tarihsel anlatılara yansımaları incelenmemiştir.

Sonuç olarak kanıt ve kaynakların, üçüncü şahıstan yazılmış tarihsel anlatılara yansımaları ve bu anlatıların seviyelerini tespit eden bir çalışmaya rastlanmamıştır. Hâlbuki üçüncü tekil şahıstan yazdırılan anlatılar, tarihsel düşünmeyi etkileyebilecek bir potansiyele sahip olabilir. Çünkü iddia ve kanıt arasındaki bağlantı, diğer sunum biçimlerinin yanı sıra, yazı ile en açık bir şekilde ortaya çıkmaktadır (Brooks, 2008). Bununla birlikte kanıt ve kaynaklar, özdeşim kurma veya olgusal bir nakletme görevi verilmeden incelenebilir ve tarihsel anlatılar, çok boyutlu bir perspektiften yazdırılabilir. Diğer yandan kanıt ve kaynakların kullanımını içeren çalışmalar, genellikle ilişkiye odaklanan nicel araştırmalardır. Oysaki nitel araştırmalar, kanıt ve kaynak kullanan öğrencilerin, tarihsel düşünme üzerinde şekillendirici etkisi olan farklı durumların her birinin bağlamlarını, çoklu perspektiflerinin bütünsel analizini, ayrıntılı bir şekilde yazdıkları anlatılarını, kendi perspektifleriyle ortaya çıkarabilir. Üstelik nitel bir araştırmada, öğrenciler, kanıt ve kaynak analizi yaparken, yardımcı araştırmacı olarak çalışmaya dâhil edilebilirler.

Çeşitli kanıt ve kaynaklar incelenerek, nitel araştırma yaklaşımı kullanılarak, öğrencileri araştırmacı olarak çalışmaya dâhil ederek, kanıt ve kaynakların, üçüncü şahıs bir dille yazdırılan tarihsel anlatılara yansımaları ve bu anlatıların seviyeleri ortaya çıkarılabilir. Bununla birlikte öğrencilerin, tarihsel olayları nasıl kavradıkları ve bunları nasıl yazıya geçirdikleri anlaşılabilir. Böylece araştırmacılar, tarihsel anlatılara yönelik farklı yaklaşımlar geliştirebilirler. Program geliştirme uzmanları bunlara yönelik desen çalışmaları ve öğretmenlerde, ders planlarını buna uygun olarak yapabilirler. Bu bağlamda araştırmanın amacı, kanıt ve kaynakların tarihsel anlatılara 
yansımalarını ortaya çıkarmak ve öğrencilerin anlatı seviyelerini betimlemektir. Araştırma bu amaçla, iki soruyu cevaplamaya odaklanmıştır:

1- Kanıt ve kaynaklar, öğrencilerin üçüncü şahıstan yazılmış tarihsel anlatılarına nasıl yansımaktadır?

2- Kanıt ve kaynakları kullanan öğrencilerin, tarihsel anlatı seviyeleri nasıldır?

\section{Yöntem}

Araştırma sorularını yanıtlamak için, nitel araştırma yöntemi kullanılmıştır. Merriam (1998: 11), nitel araştırmayı "bir olguyu, süreci ya da ilgili kişilerin bakış açıları ve dünya görüşlerini keşfetme ve anlamaya çalışma” olarak tanımlamıştır. Bu bağlamda araştırmada, kanıt ve kaynak kullanan ortaokul 8. sınıf öğrencilerinin, tarihsel anlatılarına yansıyan bakış açılarını tespit etmek amaçlanmıştır. Aynı zamanda nitel araştırma yöntemi, Lincoln ve Guba (1985) tarafindan özetlendiği gibi, katılımcıların doğal ortamlarında meydana gelen paradigmatik varsayımları yansıtmalıdır. Buna uygun olarak bu araştırma, katılımcılara yönelik herhangi bir manipülasyonu içermemiş ve katılımcıların doğal ortamlarında (sınıf ve kütüphane) yapılmıştır.

\subsection{Araştırmanın Yaklaşımı ve Deseni}

Araştırma, durum çalışması yaklaşımına uygun olarak yapılmıştır. Stake (1995), durum çalışmasını, gerçek hayat olaylarının bütünsel olarak incelenmesi ve bu sayede olaylardaki anlamlı özelliklerin ortaya çıkarılması olarak tanımlamıştır. Bununla paralel olarak bir durum çalışması, belirli bir ilgi alanına ya da olguya ilişkin bir bakış açısı elde edilmesini sağlamakta, deneyimleri arttıran içgörüyü açığa çıkartmakta ve anlamların keşfini sağlayan bir duruma yardımcı olmaktadır (Merriam, 2009).

Durum çalışması, bu araştırmaya uygun olmuştur. Çünkü araştırmaya az sayıda öğrenci katılmış (14 öğrenci) ve katılımcılar sınırlı bir sistemi temsil etmiştir. Bununla paralel olarak katılımcıların anlatıları farklı bakış açılarını içermiştir. Böylece, kanıt ve kaynakların yansımaları bütünsel olarak incelenmeye ve "bağlamsal yorumlar" (Merriam, 2009: 42) ortaya çıkarılmaya çalışılmıştır. Bununla birlikte, araştırmacının, zaman içerisinde sınırlandırılan bir durumu, çoklu veri toplama araçları (gözlem, doküman ve görsel-işitsel araçlar) kullanarak, ayrıntılı bir şekilde incelediği, duruma bağlı temaları ortaya çıkardığı (Creswell, 2007) bir araştırma desenlenmiştir. Bunlara ek olarak, durum çalışması, bu araştırmayı yönlendiren sorular gibi, süreç içerisinde meydana gelen olayların yansımalarıyla ilgilenen "nasıl" sorularını yanıtlamak için uygundur (Yin, 2003). Öte yandan bu araştırma Davey'in (1991) belirttiği gibi, sonuçlara dayanarak, olayın neden o şekilde oluştuğunu ve gelecek çalışmalar için öncelikli olan konuları ortaya çıkarmıştır.

Araştırma, bütüncül tek durum desenine uygun olarak yapılmıştır. Bütüncül tek durum desenlerinde, tek bir analiz birimi bulunmaktadır (Yin, 2003). Aynı şekilde bu araştırmada, ' kanıt ve kaynak kullanma süreci' analiz birimi olarak belirlenmiştir. Eğer bütüncül tek durum desenleri, tek bir olay içinde iki alt birimi inceliyorsa, buna içe içe geçmiş çoklu durum deseni denilmektedir (Yıldırım ve Şimşek, 2016). Bu araştırmada, kanıt ve kaynak kullanma süreci, bütünsel durumu; bunun tarihsel anlatılara ve tarihsel anlatı seviyelerine yansımaları da, onun iki alt birimini oluşturmuştur. Şekil 1, bu deseni göstermektedir.

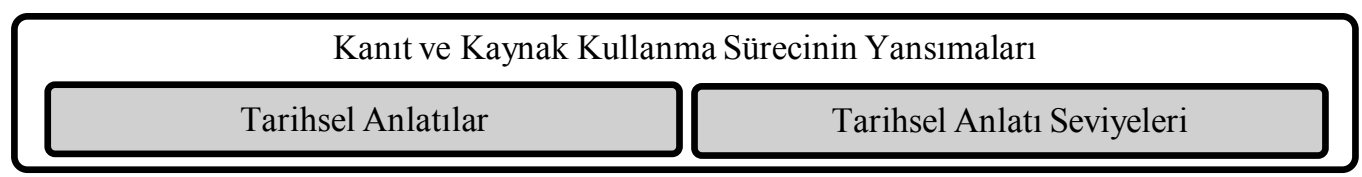

Şekil 1: Araştırmada Kullanılan İç İçe Geçmiş Çoklu Durum Deseni 
Şekil 1 incelendiğinde, birbirinden farklı iki birimin olduğu ve bu iki birimdeki değişimin, kanıt ve kaynaklara bağlı olarak meydana geldiği görülmektedir.

\subsection{Katılımeılar}

Katılımcılar, Sakarya'nın kırsal bir bölgesinde yer alan, MEB'e bağlı resmi bir ortaokulun, 8. sınıfında öğrenim gören öğrencilerden oluşmuştur. Araştırma, 2018/2019 eğitim-öğretim yılının, 1. döneminde gerçekleştirilmiştir. Araştırmaya, 9'u kız, 5'i erkek olmak üzere, 14 öğrenci katılmıştır. Öğrenciler, ölçüt durum örnekleme yöntemine uygun olarak seçilmiştir. Bu bağlamda, kanıt ve kaynaklarla çalışma deneyimi her öğrencide farklı olabileceği için, daha önce kanıt ve kaynaklarla çalışma deneyimi olmayan öğrenciler, araştırmaya dâhil edilmiştir. Katılımcılara ait bazı demografik özellikler, tablo 2'de sunulmuştur.

Tablo 2: Katılımcıların Demografik Özellikleri

\begin{tabular}{lll}
\hline Değişken & & Kişi sayısı (Yüzde \%) \\
\hline \multirow{2}{*}{ Cinsiyet } & Erkek & $5(\% 36)$ \\
& Kız & $9(\% 64)$ \\
\hline \multirow{2}{*}{ Yaş } & 13 & $1(\% 7)$ \\
& 14 & $11(\% 77)$ \\
& 15 & $2(\% 15)$ \\
\hline \multirow{2}{*}{ Aile gelir } & Asgari ücretten az & $1(\% 7)$ \\
durumu & Asgari ücret (2020 TL) & $1(\% 7)$ \\
& 2020-2500 TL & $2(\% 15)$ \\
& 2501-3000 TL & $8(\% 58)$ \\
& 3001-3500 TL & $1(\% 7)$ \\
& 3501 TL ve üzeri & $1(\% 7)$ \\
\multirow{2}{*}{ Ailenin } & Batı Karadeniz Bölümü & $1(\% 7)$ \\
yöresel & Doğu Karadeniz Bölümü & $4(\% 28)$ \\
kökeni & Deliorman (Bulgaristan) & $8(\% 58)$ \\
& Erzurum-Kars Bölümü & $1(\% 7)$ \\
\hline
\end{tabular}

\subsection{Veri Toplama ve Kaynakları}

Araştırmacı katılımcı gözlemci olarak, veri toplama ve analizinde, ayrıcalıklı ve kısıtlı bir pozisyonda (Creswell, 2003) yer almıştır. Ayrıca araştırmacı, araştırma boyunca öğretmen ve araştırmacı olmak üzere, ikili bir rol üstlenmiştir. Bu durum, sınıf içi değişkenleri denetleme ve grup dinamiklerini not etmede katkı sağlamıştır. Bunun ötesinde, öğretmen/araştırmacının, araştırma başlamadan yaklaşık 1 yıl önce, katılımcı öğrencilerle tanışması, "doğal, göze batmayan ve tehditkâr olmayan bir şekilde ögrencilerle etkileşime girilmesine", (Bogdan ve Biklen, 2007: 39) ortam hazırlamıştır.

Veri toplama kaynakları arasında; video kaydı olan grup tartışmaları, katılımlı gözlem ve tarihsel anlatılar yer almıştır. $\mathrm{Bu}$, belirli bir veri toplama kaynağının sınıllılıklarını azaltarak, veri toplama kaynaklarının çeşitlendirilmesini (Maxwell, 2005) sağlamıştır. Araştırma, MEB' in ortaokul 8. sınıflar için hazırladığı, T.C. İnkılap Tarihi ve Atatürkçülük ders kitabındaki üniteler temel alınarak yapılmıştır. Bu bağlamda ders kitabının, 2. ünitesi 6. konusu olan, "Bir Milletin Yemini: MisakıMilli” ile 3. ünitesi 2. konusu olan, "Batı Cephesi”, araştırma konusu olarak seçilmiştir. Çünkü bu konuların, öğrencilerin çeşitli kanıt ve kaynakları kullanma ve farklı bakış açılarından tarihsel olayları görebilmelerini sağlama gibi, birtakım avantajları bulunmaktadır.

Grup tartışmalarının, kanıt ve kaynakları kullanan öğrencilerin, fiziksel ve psikolojik tepkilerini değerlendirmek, sözlü ve yazılı anlatımlarının uyuşup uyuşmadığını kontrol etmek gibi yararları olmuştur. Katılımlı gözleme, yazdıklarını okuyan ve düşüncelerini savunan öğrencilerin, hareketlerini bir bütün olarak kaydetmek için ihtiyaç duyulmuştur. Bunlarla birlikte; "tarihsel 
temsilci, dil, bakış açısı ve önyargı" (Yeager ve diğerleri, 1998: 20) gibi unsurları, öğrencilerin anlatılarına nasıl yansıttıkları, tarihsel anlatılar aracılığıyla belirlenmiştir.

Araştırma kapsamındaki konuların tamamı sınıfta işlenmiştir. Bu bağlamda önce, ders kitabındaki ilgili konular, kazanımlarla ilişkilendirilerek işlenmiştir. Konular işlenirken, birincil ve ikincil elden kaynaklardan yararlanılmıştır. Bu amaçla, "T.C. İnkılap Tarihi ve Atatürkçülük ders kitabı", "Halil Dikmen'in İstiklal Savaşı 'nda Mermi Taşıyan Kadınlar adlı tablosu”, "Atatürk'ün

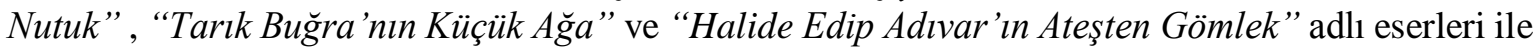
o dönemlere ait "gazete, fotoğraf ve belgeseller" kullanılmıştır.

Birinci aşamada, kanıt ve kaynaklar "tarafsız ve önyargısız" bir şekilde öğrencilerin incelemesine sunulmuştur. Bu aşamada öğrencilere sadece, kanıt ve kaynakların odağındaki tarihsel dönem hakkında olgusal bilgi verilmiştir. Böylece yanlı ve taraflı bir bakış açısıyla, kanıt ve kaynakların seçilmesi ve anlatıların bunlara dayalı olarak inşaa edilmesi önlenmek istenmiştir.

İkinci aşamada, kanıt ve kaynakları, konularla bağlantılı olarak inceleyen öğrencilerden, üçüncü şahıs zamiriyle, tarihsel anlatılar yazmaları istenmiştir. Bu anlatılar, ' kanıt ve kaynakları kullanın" şeklinde yönergeler verilmeden yazdırılmıştır. Çünkü bunun aksi, araştırmada kanıt ve kaynak kullanımı dışında, öğretmenin de etkisini doğurabilirdi.

Üçüncü aşamada, anlatılar okunmuş ve grup dinamiklerini not etmek için, tartışmalar yapılmıştır. Araştırmacı bu esnada moderatör görevini üstlenmiş ve tartışmayı belli bir tarafa yönlendirmemeye çalışmıştır. Bu, herhangi bir manipülasyondan kaçınmak için gerekli görülmüştür.

Dördüncü aşamada, her bir konunun bitimini takiben öğrencilere, daha ayrıntılı ve bütünsel anlatılar yazdırılmıştır. Böylece anlatıların, konu bütünlüğünden uzak kalması önlenmeye çalışılmıştır. Aynı zamanda öğrencilerin belli bir konuya ilişkin, hem kısmi hem de bütünsel düşünceleri alınabilmiştir.

\subsection{Veri Analizi}

Birinci araştırma sorusunu cevaplamak için veriler, tümevarımsal analize tabi tutulmuştur. $\mathrm{Bu}$ bağlamda her bir veri seti baştan sona okunmuş ve daha sonra bilgisayara kaydedilmiştir. Ardından kodlamanın nasıl yapılacağı belirlenmiştir. Bununla paralel olarak, grup tartışmaları ve gözlemden elde edilen notlar ile tarihsel anlatı kayitlarının, nasıl bir sıralamayla analiz edileceğine (Creswell, 1994), karar verilmiştir. Bu durum, verilerin görselleştirilmesini gerektirmiş ve verilere yönelik matrisler oluşturulmuştur. Verilerin tam bir dökümü yapıldıktan sonra, verilerdeki farklılık, desen ve yapıları ortaya çıkarmada yardımcı olması için, verilerin satır satır kodlamasına (Seidel ve Kelle, 1995) geçilmiştir. Bu aşamadan sonra, anlatıların ön analizi için yapılan kodlamalar, grup tartışmaları ve katılımlı gözlemden elde edilen notlarla ilişkilendirilerek; veriler, kategorilere indirgenmiştir.

Veri indirgemesinden sonra, ilk kodlama turunda ulaşlan 20 kategori ve 85 in vivo kodu (kişisel alıntı kodu), bir tabloda gösterilmiştir. Bu bağlamda Merriam (2009), ilk analizler tamamlandığında ortaya çıkan temaların ön hazırlık özelliği taşıdığını ve henüz kodların hangi kategoriler altında gruplandırılabileceğinin bilinemeyeceğini ifade etmiştir. Öte yandan bu durum, çoklu veri setinin içselleştirilmesine izin vermiş ve kodlardaki benzerlik ve farklılıkları aramak için, kategorileri yansız olarak incelemeyi sağlamıştır (Bogdan ve Biklen, 2007).

Satır satır kodlama yapıldıktan ve geçici kategoriler oluşturulduktan sonra, daha büyük yapıları ortaya çıkarmak için, betimsel kodlar oluşturulmuştur. Ardından bunlar üzerinde veri indirgeme işlemi uygulanmış ve kategoriler belirlenmiştir. Bu bağlamda başlangıçta beliren 20 kategori, kodların grupsal ayrımından sonra, 5 kategoriye düşürülmüştür. Son veri analizi adımında, bu kategoriler, 2 temaya indirgenmiştir. Bu temalar, kategorilerin kendi içindeki benzerlik ve 
aralarındaki farklılığa uygun olarak oluşturulmuştur. Daha sonra veri tabanında, temaları temsil edebilecek doğrudan alıntılar aranmıştır.

İkinci araştırma sorusuna yönelik olarak, önceden var olan ana temalar kullanılarak, tipolojik veri analizi (Hatch, 2002) yapılmıştır. Bu bağlamda Shelmit'in (2000) tarihsel anlatı seviyeleri, ana temalar olarak belirlenmiştir. İlk aşamada bu seviyelere uygun olarak kodlanan veri seti, kanıt ve kaynak kullanımı ile tarihsel anlatılar arasındaki ilişkiyi ortaya çıkarmıştır. İlk kodlamadan sonra, tüm veriler tipolojik bir kategori içerisine dâhil edilmiş ve daha sonra tutarlılık açısından denetlenmiştir. Ardından verilerin içerisindeki bağlantılar, anlatı seviyelerine uygun olarak incelenmiştir. Bu çerçevede verilerin içinde, ana tema ya da kategorilerle ilgili söz ve söz öbekleri aranmıştır. Tarihsel anlatı ve tarihsel anlatı seviyeleri arasındaki ilişkiler ortaya çıkarıldıktan sonra, verileri tarihsel anlatı seviyelerine bağlayan ana temalar için, veri kalıpları ve desenler oluşturulmuştur. Anlatıların birden fazla kategori ve ana temaya uyduğu tespit edildiğinde, bunlara yönelik toplam atıflar oluşturulmuştur. Toplam atıflara göre anlatılar, belirli seviyelerde gruplandırılmıştır. En son aşamada verilerin içinde, bu gruplandırmalarla tutarlı olmayan örnekler (Endacott, 2013; Glesne, 2015) aranmıştır. İlk bulgular kodlamadaki kalıp, bağlantı ve ana temalar arasındaki ilişkilerden oluşturulmuş (Endacott, 2013) ve bunlar doğrudan alıntılarla desteklenmiştir. Son veri analizi adımı, tüm veri setini, ana tema-kategori ve kodlardaki tutarlılık için denetlemek olmuştur.

\subsection{Güvenilirlik ve Geçerlik}

Nitel araştırmanın avantajlı yönlerinden biri, özellikle bir durum çalışmasının, araştırmacının, veri toplama ve analizinde temel araç olması ve gerçekliğin yorumlarına, katılımlı gözlem ve görüşmeler yoluyla ulaşmasıdır (Merriam, 2009). Bu bağlamda araştırmada, araştırmacı, veri toplama ve analizinde ön planda olmuş; anlatı, alan notları ve grup tartışmalarında, katılımcıların eylemleri belgelenmeye çalışılmıştır.

Araştırmanın iç denetimi için, bazı işlemler yapılmıştır. Öncelikle veri setine yönelik katılımcı teyitleri alınmış; böylece sınıf içi gözlemler ve grup tartışmaları sırasında alınan notların gerçeği yansıtmasına çalışılmıştır. Bununla birlikte bulguları doğrulamak için, anlatılardan, doğrudan ve dolaylı alıntılar yapılmıştır. Sonuç olarak, katılımcıların söz ve davranışları, yanlış bir şekilde yorumlanmamaya ve bakış açıları olduğu gibi ortaya konulmaya (Merriam, 2009) çalışılmıştır.

Güvenirliği arttırmak için Silverman (1993), araştırmacının, araştırmaya yönelik işlemsel basamakları belgelemesi ve kategorilerin tutarlı bir şekilde oluşturulduğunu kanıtlaması gerektiğini söylemiştir. Bu araştırmanın işlemsel basamakları özetlenmiş ve işlemsel basamaklar, ortaokul 8. sınıfta kanıt ve kaynakların yansımalarını tespit etmek için, başka durumlarda da kullanılabilmeye hazır hale getirilmiştir. Bununla paralel olarak Shelmit'in (2000) tarihsel anlatı seviyelerinin, öğrencilerin anlatılarını analiz etmek için, nasıl işe koşulabileceği örneklendirilmiştir. Aynı zamanda, kodlayıcılar arası görüş birliğini sağlamak için, sosyal bilgiler alanından 3 uzmana başvurulmuştur. $\mathrm{Bu}$ uzmanlar birbirlerinden bağımsız olarak, betimsel kodların, hangi kategori ve temaların altında sınıflandırılabileceğine yönelik görüşlerini sunmuşlardır. Görüşler arasında, \%80 oranında bir anlaşma elde edilmeye çalışılmıştır. Çünkü Miles ve Huberman (1994), kodlayıcılararası görüş birliğinin sağlanabilmesi için, görüşler arasında en az \%80 oranında bir uyuşumun olması gerektiğini belirtmişlerdir.

Silverman (1993), kategorilerin veri setine standart bir şekilde uygulanması ve veri setine yönelik dökümlerin standardizasyonun sağlanmasının, güvenirliği artırabileceğini ifade etmiştir. Yin (1989) de, nitel araştırmaların diğer ortamlarda da uygulanması için, ayrıntılı bir araştırma protokolünün geliştirilmesi gerektiğini savunmuştur. Bu araştırmada, tüm kategoriler, standart bir şekilde tanımlanmış ve kanıt ve kaynakların tarihsel anlatı ve tarihsel anlatı seviyelerine 
yansımalarını belirlemek için kullanılmıştır. Bununla birlikte aynı standartlar kullanılarak, veriler kodlanmış ve en son olarak bulgulara ulaşılmıştır. Bunlara ek olarak bulgulara yönelik katılımeı teyitleri alınmıştır.

Veri toplamak için, birden fazla yöntem, teknik ve araçtan yararlanılmıştır. Bu durum, çeşitliliği sağlayarak, araştırmanın geçerliğini arttırmıştır. Aynı zamanda çeşitlemede en öncelikli amaçlardan biri, verilerin doygunluğa ulaşmasıdır. Bunu sağlamak için, katılımcılara iki ek anlatı daha yazdırılmış ve tekrar veri analizi yapılmıştır. Son olarak etik ihlaller olmaması için, katılımcılara kod adı verilmiş, araştırma, öğretim sürecinde gerçekleştirilmiş ve katılımcılar, kanıt ve kaynaklarla çalıştıkları için, araştırmadan fayda sağlamışlardır.

\section{Bulgular}

Veri analizi sonucunda elde edilen bulgular, araştırma sorularına göre sunulmuştur.

\subsection{Kanıt ve Kaynak Kullanımının Tarihsel Anlatılara Yansımaları}

T.C. İnkılap Tarihi ve Atatürkçülük dersinin 2. ünitesi, "Bir Milletin Yemini: MisakıMilli”, "Büyük Millet Meclisine Karşı Çıkarılan Ayaklanmalar", "Geçersiz Bir Antlaşma: Sevr Antlaşması”" ve 3. ünitesinde yer alan "Londra Konferansı" konuları, kanıt ve kaynaklar kullanılarak işlenmiş ve dersin son 15 dakikasında, konuyla ilgili öğrencilere tarihsel anlatılar yazdırılmıştır. Her bir anlatı, T.C. İnkılap Tarihi ve Atatürkçülük ders defterine yazdırılmıştır. Ders bitiminde bu defterler toplanmış ve tümevarımsal olarak analiz edilmiştir.

Verilerin analizi sonucunda, kanıt ve kaynak kullanımının, tarihsel bilgiyi kazandırma ve düşünmeyi geliştirme açısından, çeşitli yansımalarının olduğu tespit edilmiştir. Bu bağlamda tarihsel bilginin kazanılması teması altında, tarihsel bilgi edinimi ve tarihsel bağlamsallaştırma kategorileri gruplandırılmıştır. Tarihsel bilgi edinimi kategorisi altında, kronolojik ve dönemsel bilgiye sahip olma; tarihsel bağlamsallaştırma kategorisi altında ise, döneme özgü çıkarım ve tarihsel koşulların analizini yapma, betimsel kodları sınıflandırılmıştır.

Tarihsel düşünmenin geliştirilmesi teması altında, niyet analizi, duygulara temas ve özdeşleşme kategorileri gruplandırılmıştır. Niyet analizi kategorisi altında, çoklu bakış açısı alma ve aktörlerin rolünü saptama; duygulara temas kategorisi altında, endişelere ortak olma ve milliyetçi söylemler; özdeşleşme kategorisi altında ise, kimlik kaybı ve sempatik tepki verme betimsel kodları sınıflandırılmıştır. Bu analizler sonucunda elde edilen bulgular, tematik olarak sunulmuştur.

\subsubsection{Tarihsel Bilginin Kazanılması}

Tarihsel anlatılardan elde edilen ilk bulgu, T.C. İnkılap Tarihi ve Atatürkçülük dersinde, tarihsel bilginin, kanıtlara dayalı olarak kazanılması olmuştur. Başka bir ifadeyle analiz sonucunda, öğrencilerin kanıt ve kaynakları inceleyerek, olgusal bilgiyi kazanabildikleri ve bu bilgiyi tarihsel bir anlatı inşaa ederken kullanabildikleri ortaya çıkmıştır. Örneğin, öğrencilerden, Londra Konferansı'na katılan devletlerin amaçları hakkında bildiklerini yazmaları istendiğinde, Nalan kod adlı öğrenci şunları yazmıştır:

“... En önemlisi de Sevr Antlaşmasını onlara (BMM) kabul ettirmek.

Kanıt 1: Nutuk'a göre, onların (Itilaf Devletleri) amacı, bizler[e] (BMM) o antlaşmayı koşulsuz şartsız kabul ettirmekti veya Sevr'i yumuşatarak kabul ettirmek.

Kanıt 2: Misak-ı Milli kararlarına göre önemli olan, Osmanlı Devleti'nin toprakları ve tam bağımsızlık[tır].

Kanıt 3: T.C. Inkılap Tarihi ve Atatürkçülük ögretmeninin anlattıklarına göre, bizlerin korumak istediği tam bă̆ımsızlıktır." 
Alınan pasajda öğrencinin, anlatısına, birincil (Misak-1 Milli belgesi) ve ikincil (Nutuk ve sosyal bilgiler öğretmeni) elden kaynakları, yansıttığı görülmektedir. Buna paralel olarak Nutuk, Misak-1 Milli kararları ve sosyal bilgiler öğretmeninin, Nalan'ın düşüncelerini biçimlendirmek için, kaynak olarak kullanıldığı ve tarihsel bir anlatı inşaa edilirken, kanıtlara dayalı olarak tarihsel bilginin kazanıldığı tespit edilmiştir. Ayrıca bu bilginin çözümleme düzeyinde bir bilgi olduğu da belirtilmelidir. Bu bağlamda öğrencinin, soruya uygun olarak, asıl anlatmak istediğinin, tarihsel bir olayla ilgili (Sevr Antlaşması), iki farklı amaç yapısını (BMM ve İtilaf Devletleri) ortaya koymak olduğu anlaşılmaktadır. Buna paralel olarak, anlatının ilk cümlesine 'çünkü' sözcüğu ilave edilip, anlatı tekrar okunduğunda; anlatıdaki kanıtların belli bir açıklamayı temellendirmek için kullanıldığı görülmektedir.

Erdal kod adlı öğrenci anlatısında, “... Çünkü hocamızın dediğine göre, İtilaf Devletleri Sevr Antlaşması'nı yumuşatarak, BMM'ye imzalatmak istiyorlardı.” şeklinde yazmıştır. Bu pasajda geçen, "hocamızın dediğine göre" sözüyle, sosyal bilgiler ögretmeni referans gösterilmiştir. Bu durum, tarihsel bilginin kanıtlara dayalı olarak kazanıldığının başka bir göstergesi olabilir.

Aynı tema için, Burhan kod adlı öğrenci, anlatısında şunları yazmıştır: “...T.C. İkılap Tarihi kitabımızdan ögrendiğime göre, 21 Şubat-12 Mart 1921 tarihinde, Londra Konferansı toplandl.

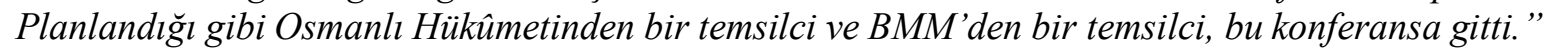
Öğrenci anlatısından, kronolojik bir bilginin (21 Şubat-12 Mart 1921), T.C. İnkılap Tarihi ve Atatürkçülük ders kitabından öğrenilmiş olduğu anlaşılmaktadır. Buna ek olarak Ceyda kod adlı öğrenci de anlatısında, “... Misak-ı Milli kararları: Türk yurdunun sınırlarının çizilmesi, kapitülasyonlara karşı çıkılması, ulusal egemenliğin önemi, uluslararası eşitlik ilkelerine vurgu yapılmasıdır." şeklinde yazmıştır. Tüm bu veriler birlikte değerlendirildiğinde, kanıt ve kaynak kullanımı sayesinde, tarihsel bilginin elde edilebileceği söylenebilir.

Bunlara ek olarak anlatılardan, öğrencilerin, tarihsel bağlama atıfta bulunma eğiliminde oldukları tespit edilmiştir. Bu bağlamda kanıt ve kaynak kullanımı, öğrencilerin, günümüzün koşulları ve yaşam şekli ile geçmişin koşulları ve yaşam şekli arasında, zamansal bir fark olduğunu anlamalarına destek olmuştur. Dolayısıyla günümüz ve geçmişin şartlarının benzemezliğini, öğrencilerin anladıkları düşünülmektedir. Bu kapsamda öğrencilere "Londra Konferansı'na BMM temsilcisi olarak katılan Bekir Sami Bey nasıl bir konuşma metni hazırlamıs olabilir?" sorusu yöneltilmiştir. Soruyla ilgili olarak, Çiğdem kod adlı öğrenci anlatısında şunları yazmıştır:

“... Nihayet söz sirası Bekir Sami Bey’e gelmişti. O zamanın şartlarındaki Türkiye’de asıl amaçlar özgürlük, bağımsızlık ve eğitimdir. Bizler hiç kimsenin boyunduruğu altında yaşamayı kabul etmiyoruz. Bizler bağımsızlık, özgürlük ve çağdaşllk yolunda ilerleyip, [bizim] hür ve özgür iradeye sahip bir devlet ve millet olduğumuzun göstergesi olarak, burada bulunmakta olduğumuzu belirtmek isterim."

Yukarıdaki alıntı, dönemin şartlarının göz önünde bulundurularak, tarihsel bir anlatı inşaa edildiğinin bir göstergesi olabilir. Öyle ki o zamanki düşünce iklimi ve politik hedeflerinin, Çiğdem' in anlatısına “O zamanın şartlarındaki Türkiye'de asıl amaçlar özgürlük, bağımsızlık ve eğitimdir." şeklinde yansıdığı görülmektedir. Bunun yanı sıra, döneme özgü algının tarihsel bir aktörün bakış açısından, "Bizler hiç kimsenin boyunduruğu altında yaşamayı kabul etmiyoruz." şeklinde serimlenmeye çalışılması, bağlama vurgunun diğer bir kanıtı olabilir. Buradan da, Türk milletinin amaçlarının, "asıl amaçlar özgürlük, băgımsızlık ve eğitimdir" şeklinde ortaya konulması, tarihsel bağlamın genişletilmeye; aynı zamanda tarihsel bir genelleme yapılmaya ve sonuç çıkarılmaya çalışıldığının işaretleri olmaktadır.

Emrah kod adlı öğrenci, tarihsel bağlama olan vurgusunda, geçmiş ve şimdiki zamanın farklılığına işaret eden bir değişimi, anlatısında yansıtmaktadır. Emrah şunları yazmıştır: “... Çünkü Osmanlı Devleti, tam 10 yıldır savaş yap[maktadır], artık savaş yapmaktan bıkmış bir durumdadır. 
Bu durum onlarda barışa özlem uyandırmaktadır." Emrah Osmanlı Devleti'nin, o zamanki psikolojik yapısını, "artık savaş yapmaktan bıkmış bir durumdadır. Bu durum onlarda barışa özlem uyandırmaktadır." şeklindeki saptamalarıyla, genel olarak ortaya koymakla kalmamış; bunun yanı sıra, savaş yapmaktan bıkmış olabileceğini tarihsel bir tahmin olarak öne sürmüştür.

Mürüvvet kod adlı öğrencinin, tarihsel bağlamsallaştırmayı anladığının bir göstergesi olan yazısı şu şekildedir: "O dönemde savaş koşulları çok ağırmış. Yiyecek, tahıl ve ekmek zor bulunurmuş. Askerler yokluktan lastik ayakkabı ile gezerlermiş.” Bu yazıda, savaş koşullarının zorluğuna ve bununla bağlantılı olarak gıda ihtiyaçlarının karşılanamamasına değinilmiştir. Buna ek olarak, askerlerin lastik ayakkabı giymelerinin yokluk belirtisi olarak anlaş1ldığı düşünülmektedir. Özetle, dönemin ekonomik koşullarına vurgu yapıldığı sonucuna ulaşılmıştır.

Ayhan kod adlı öğrenci, Mürüvvet kod adlı öğrenciyle paralel görüşler paylaşmıştır. O, anlatısında Osmanlı Devleti'nin 1911'den beri savaştı̆̆ını ve bu yüzden yokluk çektiğini belirtmiştir. $\mathrm{Bu}$ duruma, yiyecek ve giyecek maddelerinin azlığını kanıt göstermiştir.

\subsubsection{Tarihsel Düşünmenin Geliştirilmesi}

Anlatıların analizi sonucunda, öğrencilerin tarihsel temsilcilerin amaç ve niyetlerini irdeleyebildikleri tespit edilmiştir. Bu bağlamda tarihsel temsilcilerin ayrı ayrı veya birlikte rolleri hesaba katılarak, anlatıların inşaa edilmeye çalışıldığı söylenebilir. Dolayısıyla öğrencilerin, tarihsel kararların arka planındaki niyet, amaç ve beklenti gibi psikolojik unsurlara odaklandıkları düşünülmektedir. Çünkü tarafların niyetleri analiz edilmiş ve bu analizin sonuçları, tarihsel anlatılara yansımıştır. Sonuç olarak, farklı tarihsel temsilcilerin bakış açılarının alınmaya çalışıldığı saptanmıştır. Örneğin Semih kod adlı öğrenci şunları yazmıştır: "Nutuk'a göre, Bekir Sami Bey resmi olarak İtilaf Devletleri tarafindan çağrlldıktan sonra, gitti." Bu pasajda Semih' in Bekir Sami Bey nezdinde, BMM Hükümeti'nin amaçlarını analiz edebildiği anlaşılmaktadır. Çünkü Bekir Sami Bey'in Londra Konferansı'na gitmesi için, resmi olarak çağrılması gerekmektedir. Semih anlatısının devamında "BMM'nin siyasi varlığı, İtilaf Devletleri tarafindan tanınacaktır." cümlesini yazmıştır. $\mathrm{Bu}$ cümleden de anlaşılacağı gibi Semih, Bekir Sami Bey'in her koşulda Londra'ya gitmeyeceğini ve ancak resmi bir davet olduktan sonra Londra'ya gidebileceğini düşünmektedir. Yani Semih'e göre hangi koşullarda Londra'ya gidileceği bellidir. Özetle, Semih çıkarımını yaparken, BMM ve onun bir temsilcisi olan Bekir Sami Bey'in, niyetlerini analiz ettiğini göstermiştir.

Mahmut kod adlı öğrenci yazılı kanıtları analiz ederken aldığı notları, özellikle niyet analizi yaparken işe koşmuştur. Bu bağlamda Mahmut, İtilaf Devletlerinin amaçlarını ortaya koyarken, birçok yazılı kaynağa göndermede bulunmuştur. En olarak da "Itilaf Devletlerinin amacl, Sevr Antlaşması'nı imzalatmak, Bekir Sami Bey’in amacı ise, Misak-ı Milli kararların herkese ilan etmekmiş" sonucuna varmışıtır. Bu yorum, Mahmut'un, belli bir tarihsel olayı 1. tekil şahıs zamiri kullanmadan ifade etmiş olduğunu göstermektedir. Ayrıca, "İtilaf Devletlerinin amacı... Bekir Sami Bey'in amacı..." şeklindeki cümlesiyle de, tarihsel tarafların amaçlarını hesaba katmıştır.

Nalan kod adlı öğrenci Bekir Sami Bey’in Konferansa yönelik olumsuz beklentisini: “Bekir Sami Bey ... Londra Konferansı'ndan olumsuz cevap alacağını biliyordu. Fakat Bekir Sami Bey, Misakı Milli kararlarımızı da yanında tutarak, onunla beraber ilerlemeyi planladı.... Itilaf Devletlerinin 'Türkler savaşa devam ettiği [için] barlş istemiyor' yaygaracı söylentileri çürütmek amacıyla." şeklindeki cümlesiyle ifade etmiştir. Bekir Sami Bey'in Konferansa yönelik olumsuz beklentisini, Nalan nasıl bilmektedir? Nalan kantlara dayanarak, İtilaf Devletleri ve BMM Hükümeti'nin amaç ve niyetlerini analiz etmiş, iki tarafın birbiriyle uyuşmayan beklentiler içerisinde olduğunu düşünmüştür. Böylelikle amaç ve niyet farklılığını “... Bekir Sami Bey, Misak-ı Milli kararlarımızı da yanında tutarak, onunla beraber ilerlemeyi planladı .... Itilaf Devletlerinin 'Türkler savaşa devam ettiği [için] barış istemiyor" şeklindeki cümleleriyle ortaya koyarak, bir çözümleme 
(yaygaracı söylentileri çürütmek amacıyla) yapmıştır. Bununla birlikte İtilafların gizli emellerini ve BMM'nin açık taleplerini de ifade etmiştir.

Kodlanan 14 anlatı içinde, her bir öğrenci, bu örneklere benzer en az bir ifadeye sahip olmuştur. Bu iki örnekte olduğu gibi, diğer anlatı kayıtlarında da bunların görülmesi, öğrencilerin tarihsel taraf ve temsilcilere yönelik amaç ve niyet analizlerini ayrı ayrı nasıl yaptıklarını açıklamak için birer ipucu olabilir. İpuçlarına diğer bir örnek, Erman kod adlı öğrencinin anlatısında bulunmaktadır. Bu anlatıda amaç ve niyet analiziyle birlikte, döneme özgü bağlam, tarihsel bir imaj şeklinde zihinde canlandırılmıştır: “... İtilaf Devletleri Sevr Antlaşması'nı yumuşatarak, BMM'ye imzalatmak istiyorlardl. Bekir Sami Bey, İngiltere, Fransa, İtalya ve Yunanlıların karşısında tek başına orada konuşmasını yapar. Bekir Sami Bey orada Misak-ı Milli'yi kabul ettirmeye çalışmışıtır.” Bekir Sami Bey'in İtilaflar karşısında tek başına konuşma yapmasına yönelik herhangi bir kanıt parçası sunulmamış olmasına rağmen, Erman kod adlı öğrenci bu kanıya varmıştır. Bu kanı, bağlama yönelik zihinsel bir temsilin oluşturulduğuna işaret etmektedir. Aynı zamanda bu zihinsel temsilden, Konferansta İtilafların birlikte hareket ettikleri ve BMM Hükümeti'nin siyasi yalnızlık içerisinde olduğu çıkarılmaktadır. Bu anlatıdan da, her iki tarafin amaç ve niyet farklılıklarının algılandığına yönelik ipuçları elde edilmiştir.

Verilerin analizi sonucunda ortaya çıkan diğer bir bulgu, duyguların hesaba katılarak tarihsel bir anlatı inşaa edilmeye çalışılmasıdır. Başka bir ifadeyle, öğrenciler tarafindan tarihsel bir olaya yönelik duygular anlaşılmak istenmiştir. Bununla birlikte, duyguların anlaşılmaya çalışılmasında, kanıtlar, ölçüt olarak kullanılmıştır. Bu kapsamda anlatılarda hayal gücüne sınırsız bir şekilde yer verilmemiş, kaynak ve kanıtlara göre duygular belirtilmek istenmiştir. Sözü edilen duruma, Berrin kod adlı ögrencinin anlatısı örnek olabilir: “... Itilaf Devletleri planını devreye soktu ve söz Osmanlı Hükümeti temsilcisine geldiğinde Tevfik Paşa şöyle demişti: 'Ben sözü Türk milletinin hakiki temsilcisi olan BMM delegesine bıraklyorum' demiş ve İtilaf Devletlerinin oyunu bozulmuştur." Pasajdan da anlaşılacağı gibi, Berrin "İtilaf Devletlerinin oyunu bozulmuştur" diyerek, İtilaf Devletlerinin bir çeşit entrika çevirdiğini iddia etmiştir.

Emrah kod adlı ögrenci, kanıt ve kaynaklar Osmanlı Halkının psikolojik yapısıyla ilgili herhangi bir duygu unsuru barındırmasa da, anlatısında, duygusal faktörleri göz önünde bulundurmuştur. Ona göre Londra Konferansı (21 Şubat-12 Mart 1921) dönemine gelene kadar, Osmanlı Devleti aralıksız olarak 10 yıldır savaş yapmıştır ve artık savaş yapmaktan da bıkmış bir durumdadır. Yani halkta bir yorgunluk bulunmaktadır. Halkın savaş yapma azmi ve isteği azalmıştır. Böylelikle Emrah, o dönemin kanıt ve kaynaklarını analiz ettikten sonra, Osmanlı Halkının savaşa yönelik psikolojisini, duygu durumunu belirterek ortaya koymak istemiştir.

Öğrenci anlatılarının analizi sonucunda ortaya çıkan son bulgu, öğrencilerin kendilerini tarihsel temsilcilerle özdeşleştirmeleridir. Her ne kadar bu, 14 anlatıdan 5'inde karşılaşılan bir durum olsa da, tarih öğretimi açısından bu durumun ortaya koyulması faydalı olabilir. Öğrenci anlatılarına genel olarak özdeşleşme, 1. tekil şahıs zamiri kullanılarak yansıtılmıştır. Bu duruma örnek olarak Ali kod adlı öğrencinin anlatısı verilebilir: “... Biz bunlara karşılık yıllardır onca yıl kan döktü̈̆̈̈müz topraklarl size vermeyiz. Bizim tek kararımı var, o da Misak-ı Milli kararlarıdır. Biz sadece bu kararlara uyarız ve bu kararları tüm dünyaya duyuracağız." Ali kod adlı öğrenci “Biz bunlara karşılık yıllardır onca yıl kan döktügümüz toprakları size vermeyiz" şeklindeki ifadesiyle, kanıt ve kaynakların sınırından çıkarak, kendisini tarihsel temsilcilerle özdeşleştirmiştir. Ayrıca o dönemdeki duygusal atmosferi de hayal etmiştir.

Kanıt ve kaynakların tarihsel anlatılara yansımalarına yönelik tümevarımsal analiz sonuçları toplu olarak şekil 2'de sunulmuştur. 


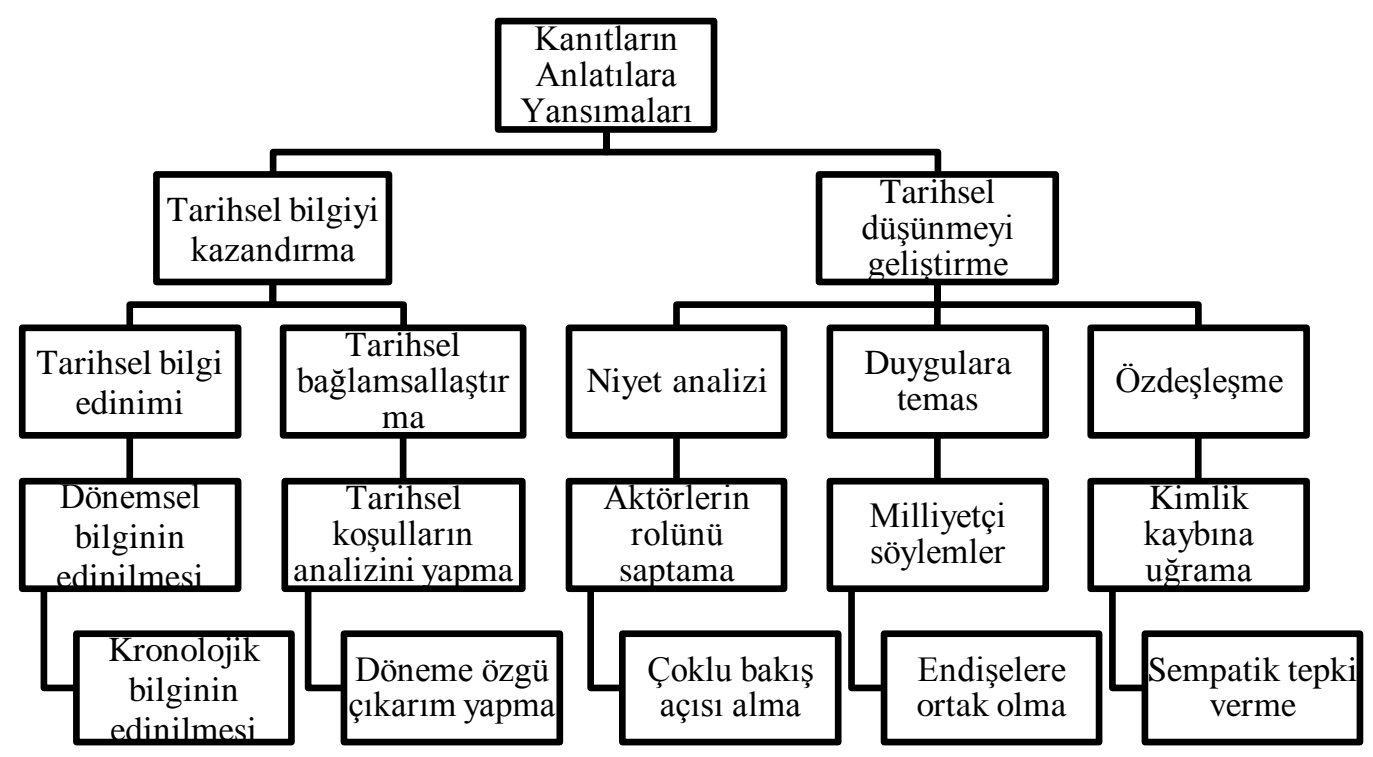

Şekil 2: Kanıt ve Kaynakların Tarihsel Anlatılara Yansımaları

Kanıt ve kaynak kullanan öğrencilerin, tarihsel anlatıları tümevarımsal analize tabi tutulmuş ve şekil 2, buna uygun olarak oluşturulmuştur. Bu süreçte kapsamlı temalara ulaşılıncaya kadar, temalar ve veri seti arasında, ileri-geri gidişler olmuştur. Sonuç olarak, tarihsel bilgiyi kazandırma ve tarihsel düşünmeyi geliştirme temaları elde edilmiştir. Yine bu bağlamda; kronolojik bilginin, dönemsel bilginin edinilmesinde işe koşulduğu; döneme özgü çıkarım yapmanın, tarihsel koşulların analizini yapmaya katkı sağladığı; çoklu bakış almanın, aktörlerin rolünü saptamaya yardım ettiği; endişelere ortak olmanın, milliyetçi söylemleri arttırdığı; sempatik tepki vermenin, kimlik kaybına neden olabildiği söylenebilir.

\subsection{Kanıt ve Kaynak Kullanımının Tarihsel Anlatı Seviyelerine Yansımaları}

Öğrencilerin tarihsel anlatıları Shemilt'in (2000), tarihsel anlatıların öğretimi ve değerlendirilmesi için öne sürdüğü kuramsal çerçeveye göre analiz edilmiştir. Bu bağlamda anlatılar, betimsel analize tabi tutulmuştur. Analiz sonuçları anlatı seviyelerine göre sunulmuştur.

Shemilt'in (2000) ortaya koyduğu kuramsal çerçevede, 1. seviye kronolojik sıralı anlatılardır. Kodlanan öğrenci anlatılarının tamamında, 1. seviyeye işaret eden ifadelere rastlanmıştır. $\mathrm{Bu}$ duruma Emrah kod adlı öğrencinin anlatısı örnek olabilir: "İtilaf Devletleri BMM['yi] Londra Konferansina davet etmiş... Ittilaf Devletleri Sevr Antlaşmasinı yumuşatarak, BMM'ye imzalatmak istiyorlardl. İtilaf Devletleri BMM'yi davet ediyor; ama BMM resmi olarak çağrıldıktan sonra, Londra Konferansına gidiyor ve Bekir Sami Bey olumlu bir sonuç çıkmayacağını bilerek konuşmasını yapıyor." Örnek alıntıda, Emrah'ın mantıklı ve sıralı bir anlatımı tercih ettiği tespit edilmiştir. Olaylar belli bir akış içerisinde ve öncelik-sonralık sırası gözetilerek yazılmıştır. Bu bağlamda örnek alıntının kronolojik akışı şu şekilde olmuştur: önce BMM davet edilmiş, sonra BMM resmi davet beklediği için tepkisiz kalmış, daha sonra resmi davet gelmiş, ardından Bekir Sami Bey Londra Konferansı'na gitmiş, en son olarak da Bekir Sami Bey konuşmasını yapmıştır. Örnek alıntıya yönelik, kronolojik eylem akışı, şekil 3'te gösterilmiştir. 


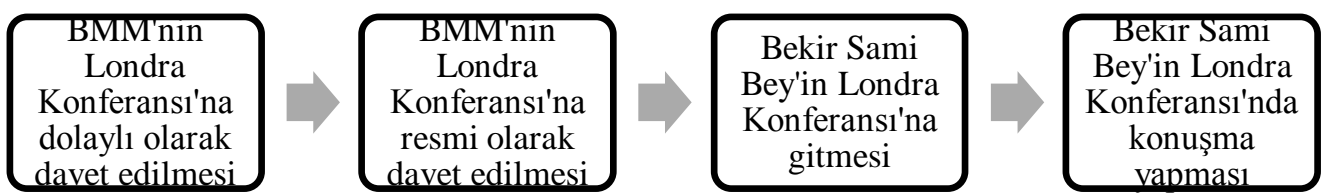

Şekil 3: Emrah Kod Adlı Öğrencinin Kronolojik Anlatı Şeması

Nusret kod adlı öğrenci, kronolojik anlatı seviyesinden başka bir örnek sunmuştur. Onun örneği şu şekildedir: “... Misak-ı Milli ile onlara işgal altındaki topraklarımızdan geri çekilmelerini, tam bağımsızlı̆̆ sağlamayı, azınlıklar ile ilgili birtakım Misak-ı Milli kararları gibi birçok kararlarımızı onlara sunarak kabul edeceğimizi söylemişlerdir.” $\mathrm{Bu}$ alıntıda, Misak-1 Milli'nin gerçekleşmesi halinde, yaşanabilecek gelişmeler sıralı bir şekilde anlatılmaktadır. Misak-1 Milli gerçekleşirse: işgal altında toprak kalmayacak, tam bağımsızlık sağlanacak, azınlık hakları belirlenecek, sonuç olarak da Türk Halkının kararları uygulanacaktır. Buna benzer ifadeler, diğer öğrencilerin kodlanan anlatılarında da bulunmaktadır. Bu durum 1. seviye tarihsel anlatının, ögrencilerin anlatılarında yer bulduğunu göstermektedir.

Seviye 2, tutarlı tarihsel anlatılardır. Kodlanan anlatıların çoğu (14 anlatının 10'u), bu seviyeye işaret eden ifadeleri içermiştir. Bu duruma tipik bir örnek, Jale kod adlı öğrencinin anlatısında bulunabilir:
“... Buraya gelmemdeki asıl amaçlardan biri ise, Türk halkının normal şartlarda yaşaması için belirlediğimiz bir karar dosyası vardır. Bu kararın adı da Misak-ı Milli kararlarıdır. Yani ulusal sinırlar anlamina gelen Misak-ı Milli'nin en önemli birkaç maddesini siz İtilaf Devletlerine sunarım. Misak-ı Milli kararlart: 1-İstanbul şehri ve Marmara'nın güvenliği sağlanmalıdır. Boğazların dünya ticaretine açılmasına Osmanlı Devleti ile ilgili devletler birlikte karar verecektir. 2- Tam bağımsızlı̆̆ımızın sağlanabilmesi için, milli ve ekonomik gelişmemizi engelleyen her türlü siyasi, adli ve mali sinırlamalar kaldırllmalıdır. 3- Mondros Ateşkes Antlaşması imzalandı̆̆ sırada işgal edilmemiş olan bölgelerin tümü, ayrlmaz bir bütündür. İşte siz İtilaf Devletlerine Misak-ı Milli kararların sundum; bu kararla sağlanmaya çalışılan şeyler; Türk yurdunun sinırlarının çizilmesi .... 28 Ocak 1920'de alınan bu kararların amacı Türk'ü iyi şartlarda yaşatabilmektir. Başka hiçbir niyetimiz yoktur..."

Jale anlatısında, 'Misak-1 Milli' kararlarını, merkezi tema olarak belirlemiştir. Bu kapsamda anlatısını şekillendirmiş ve dayanaklarını ortaya koymuştur. Misak-1 Milli'nin hedefleriyle çelişebilecek herhangi bir ifadeye rastlanmayan anlatıda, geçmişin haritası Türk tarafının bakış açısından sunulmaya çalışılmıştır. Ayrıca anlatıda, Osmanlı İmparatorluğu'nun içinde bulunduğu şartlara da göndermede bulunulmuştur. Jale "Tam bağımsızlığımızın sağlanabilmesi için, milli ve ekonomik gelişmemizi engelleyen her türlü siyasi, adli ve mali sinırlamalar kaldırılmalıdır." şeklindeki ifadesiyle, 'Misak-1 Milli' ye göndermede bulunarak, Osmanlı İmparatorluğu'nun tam olarak bağımsız olmadığını ve birçok alanda sınırlamalarla karşı karşıya kaldığını düşünmektedir. Bununla bağlantılı olarak Osmanlı İmparatorluğu'nun yabancı devletlerin işgali altında olduğunu, "İstanbul şehri ve Marmara 'nın güvenliği sağlanmalıdır." şeklindeki cümlesiyle belirtmiştir. Sonuç olarak bu anlatının, 2. seviye tarihsel bir anlatıya işaret ettiği ve o dönemlere (1920-1922) yönelik tarihsel bir anlayış oluşturmayı sağlayabileceği söylenebilir.

Tarihsel anlatıların 2. seviyesine işaret etmeyen anlatılar da bulunmaktadır. Buna örnek olarak Derya kod adlı öğrencinin anlatısı verilebilir: “... İtilaf Devletleri Misak-ı Milli'yi kabul etmiştir; ama Musul ve Suriye'yi bize vermemiştir ve bizi bu durum çok ikna etmemiş_tir] ...." İtilaf Devletleri'nin Misak-1 Milli'yi kabul etmesi (24 Temmuz 1923 tarihinde imzalanan Lozan Antlaşmas1), kanıt ve kaynak analizi yapılan dönemden (1920-1922) sonradır. Aynı zamanda Misak1 Milli' den verilen tavizler (Musul ve Suriye) de Lozan Antlaşması ile olmuştur. Ayrıca Misak-1 
Milli'nin İtilaf Devletleri tarafından kabulü, Türk tarafının istediği bir durumdur. Bu yüzden Derya kod adlı öğrencinin "bizi bu durum çok ikna etmemiş" şeklindeki cümlesi, tutarsızlığa işaret edebilir.

Seviye 3, çok boyutlu anlatılardır. Öğrenci anlatılarının bazısı (14 anlatıdan sadece 3'ü), bu seviyeye işaret etmektedir. Örneğin Remzi kod adlı öğrenci özetle, Misak-1 Milli'nin gerçekleştirilmesi gerektiğini, o dönemdeki toplumun bunu istediğini; ancak savaş yapmaktan yorulan ve savaştan bıkan bir halk olduğunun da akıldan çıkarılmaması gerektiğini belirtmiştir. Bununla birlikte antlaşma şansının bile olması, Osmanlı toplumunu sevindirmektedir. Anlatıdan çıan sonuca göre; Osmanlı toplumu savaş yapmaktan artık bıkmıştır; çünkü toplum bezmiş ve tükenmiş haldedir. Buna rağmen antlaşma ümidinin olması, toplumun moral seviyesini yükseltmektedir. Ancak antlaşma Misak-1 Milli'ye ters düştüğü için, Osmanlı toplumu kararsızdır. $\mathrm{Bu}$ anlatıda, diplomatik ve psikolojik bir durumun aynı anda hesaba katıldığı saptanmıştır.

Seviye 4, politeknik anlatı çerçevesidir. Öğrenci anlatılarının hiçbirinin tarihsel göreceliği içermediği; buna rağmen tüm anlatıların, bütünü yorumlamak için, kanıt ve kaynakların analizine dayandığ 1 tespit edilmiştir. Sonuç olarak verilerin analizi sonucunda; $1 ., 2$. ve 3 . seviyede anlatıların inşaa edildiği; buna karşıllk 4 . seviyede tam olarak bir anlatı inşaa edilemediği belirlenmiştir.

\section{Tartışma ve Sonuç}

Araştırmanın amacı, T.C. İnkılap Tarihi ve Atatürkçülük dersinde kanıt ve kaynak kullanımının, öğrenci anlatılarına yansımalarını betimlemek olmuştur. Bu amaçla her ders bitiminde, seçilen bir konuyla ilgili olarak, tarihsel anlatılar yazdırılmıştır. Ardından bu anlatılar analiz edilmiş ve analiz sonucunda, tarihsel bilginin kazanılması ve tarihsel düşünmenin geliştirilmesi temaları elde edilmiştir. Buna ek olarak öğrenci anlatılarının tamamının 1. seviye kronolojik anlatılara ve çoğunun (14 anlatının 10'u) 2. seviye tutarlı tarihsel anlatılara ve daha azının (3 anlatı) 3. seviye çok boyutlu anlatılara işaret ettiği saptanmıştır. Ayrıca hiçbir anlatının 4. seviyeyi yansıtmadığı belirlenmiştir.

Anlatıların analizi sonucunda, tarihsel bilginin kazanılması temas1 altında; tarihsel bilgi edinimi ve tarihsel bağlamsallaştırma kategorileri gruplandırılmıştır. Bu bağlamda tarihsel bilgi edinimi, öğrencilerin tarihsel zaman kavramını algıladıklarını gösterebilir. Aynı zamanda öğrencilerin, belli bir dönemle bağlantılı olarak tarihsel arka plan bilgisini de kazandıkları söylenebilir. Buna paralel olarak Bilgiç'in (2018), Tangülü ve Çıdaçı'nın (2016) ve VanSledright ve Frankes'in (2000) yapmış oldukları çalışmalarda, öğrencilerin kanıt temelli öğrenmeyle beraber tarihsel bilgiye ulaşabildikleri saptanmıştır. Benzer şekilde Kiriş’in (2009) yaptığı çalışmada, kanıt kullanımının, öğrencilerin tarihsel zaman kavramını fark etmelerinde olumlu bir etkisinin olduğu ortaya çıkmıştır.

Tarihsel bilginin kazanılması teması altında gruplandırılan diğer bir kategori, tarihsel bağlamsallaştırmadır. Tarihsel bağlamı hesaba katan öğrencilerin, tarihsel olaylardan hareketle, döneme özgü bağlamı göz önünde bulundurarak, tarihsel anlatılarını yazdıkları söylenebilir. Bununla paralel olarak da ögrenciler, kanıt ve kaynakların döneme özgü analizini yapabilmişlerdir. Öte yandan sadece kanıt ve kaynak kullanımı ile tarihsel bağlamsallaştırma ve sonuç çıkarma arasında, tek yönlü bir ilişkinin kurulmaması gerekmektedir. Aksi takdirde bağlamsallaştırma ve sonuç çıarma, tek değişkene indirgenebilir. Diğer yandan Dilek'in (2009) yapmış olduğu çalışmada da, kanıt ve kaynakları analiz eden öğrencilerin, geçmişi tarihsel bağlama uygun biçimde kurgulama becerisi gösterebildikleri tespit edilmiştir.

Anlatıların analizi sonucunda, tarihsel düşünmenin geliştirilmesi teması altında; niyet analizi, duygulara temas ve özdeşleşme kategorileri gruplandırılmıştır. Bu bağlamda öğrencilerin, kaynak ve kanıtların analizini yaparak, tarihsel olaylardaki taraflara yönelik çoklu bakış açılarını aldıkları söylenebilir. Çoklu bakış açılarını alma Wineburg (2001) tarafından, tarihsel düşünmenin öncelikli bir parçası olarak düşünülmektedir. Ona göre, bu yeti sayesinde öğrenciler, önyargılı ve 
taraflı bir bakış açısı yerine, tarihsel olayları çok yönlü yorumlayarak sonuca varabilirler. Aynı zamanda öğrencilerin, kanıt ve kaynakları inceleyerek, tarihsel olaylarda, farklı yorumların yapılabileceğinin farkına vardıkları düşünülmektedir. Buna paralel olarak Yahşi ve Keleş’ in (2013), görsel kanıt kullanımıyla ilgili yapmış oldukları çalışmada, bu araştırmanın bulgularını destekler sonuçlar rapor edilmiştir. Adı geçen çalışmada, tarih öğretiminde görsel kanıt kullanımının (gazete), çoklu bakış açısı almada etkili olduğu tespit edilmiştir. Benzer şekilde Bozkurt (2018) ve Kabapınar (2014), kanıtların çoklu bakış açısı almayla ilgili farkındalık geliştirmeye katkıda bulunduğunu saptamışlardır. Bunların aksine Özbaş (2010), tarihsel kanıt kullanımıyla ilgili yapmış olduğu çalışmada, öğrencilerin genel olarak, tarihsel olayla ilgili, iki farklı yorumun yapılamayacağı görüşünde olduklarını bildirmiştir.

Anlatıların analizi sonucunda, tarihsel düşünmenin geliştirilmesi teması altında gruplandırılan diğer bir kategori, duygulara temastır. Bu bulguyla ilgili olarak, iki farklı durumun ortaya çıktığ1 söylenebilir. Durumlardan ilki, öğrencilerin empatik, ikincisi de sempatik tepki verme eğilimde olmalarıdır. Bu iki durum, öğrencilerin, kendi deneyimlerine odaklanarak, tarihsel temsilci ve olaylardaki psikososyal iletileri alabildiklerini gösterebilir. Çünkü empati, tarihsel bir temsilcinin inanç ve deneyimlerini anlamak için, öğrencinin kendi deneyim ve paradigmasını kullanmasını gerektirmektedir (Dillenburg, 2017). Ayrıca öğrencilerin, duygularıyla beraber zihinsel güçlerini de aktif hale getirmeleri, karmaşı bir anlama etkinliği içerisinde olduklarına işaret edebilir. Çünkü geçmişe yönelik anlatılar, çok katmanlı yorum ve anlatımlara dayandırıldığı için, karmaşık bir duruma (Roord, 2009) gelebilir. Benzer bulgulara, katılımcıları üniversite öğrencileri olmasına rağmen, Bozkurt'un (2018) çalışmasında da ulaşılmıştır. Adı geçen çalışmada, kanıt temelli öğrenme uygulamaları sayesinde, öğrencilerin iletişim ve empati becerilerinin geliştirilebileceği tespit edilmiştir.

Anlatıların analizi sonucunda, tarihsel düşünmenin geliştirilmesi teması altında gruplandırılan son kategori, özdeşleşmedir. Kanıtların daha çok yerel kaynaklardan seçilmesi, bu durumun temel nedeni olabilir. Benzer şekilde Endacott'ın (2013) yapmış olduğu çalışmada, kanıtların daha çok yerel kaynaklardan seçilmesinin, tarihsel temsilcilerle (ABD başkanı Truman) özdeşleşmeye neden olduğu tespit edilmiştir. Öte yandan kanıt kullanımının özdeşleşmeye neden olabileceğini rapor eden başka çalışmaya rastlanmamıştır. Bununla birlikte tarihsel empati adına yapılan çalışmalarda, tarihsel kanıt ve kaynakların, duyguları ortaya çıkarabilecek bir şekilde kullanılması nedeniyle, öğrencilerin, tarihsel temsilcilere yönelik sempatik tepkiler gösterdikleri ve kimlik kaybına neden olabilecek aşırı yaratıcı bağlantılara girdikleri tespit edilmiştir (Dillenburg, 2017). Ancak Foster'a (2001: 20) göre, sempatik tepki göstermek ya da tarihsel bir karakterle paylaşılan bir deneyim yaşamak, olanaksızdır. Yine Foster'a göre (2001: 20), tarihsel bir temsilciye karşı sempatik tepki göstermek, "geçmişin perspektifini göz ardı etmek ve tarihçilerin geçmiş olayların güncel tercümanları olduğu gerçeğine yabancı" kalmaktır.

Öğrenci anlatılarının seviyeleri incelendiğinde; 1, 2 ve 3 . seviyeden anlatıların olduğu belirlenmiştir. Öte yandan anlatılarda 4. seviyeye işaret eden kanıt parçalarına rastlanmamıştır. $\mathrm{Bu}$ bulgu, kanıt ve kaynakların derinliğiyle ilgili olabilir. Çünkü 4. seviyeden bir anlatının inşaa edilebilmesi için, kullanılan kaynakların çok çeşitli politik ve ekonomik konuları içermesi ve anlatı çerçevesini yerelden-küresele doğru genişletmesi gerekmektedir. Ayrıca bu seviyedeki öğrencilerden, anlatılardaki ana temayı tanımlamaları ve farklı sosyal bilim disiplinleriyle kaynak arasındaki ilişkiyi vurgulamaları da beklenmektedir. Bununla bağlantılı olarak Drake ve Brown (2003), tarihsel düşünme stratejisini tartıştıkları yazılarında, 5 adımda kaynakların okunmasını salık vermiş̧lerdir. $\mathrm{Bu}$ araştırmada, öğrencilerin ilk üç adımı (kaynağın betimlenmesi ve analizi, tarihsel bağlamın analizi) yapabildikleri; ancak son 2 adımı (anlatıdaki ana temayı bulma ve sosyal bilim disiplinleriyle kaynak arasındaki ilişkiyi gösterme) yapamadıkları tespit edilmiştir. Araştırmaya katılan öğrencilerin, henüz 14 ve 15 yaşlarında olmaları ve kırsal bir yerleşim yerinde oturmaları bu 
durumun temel nedenlerinden biri olabilir. Aynı zamanda bu durum, araştırmanın sınırlılığını oluşturmuştur. Çünkü bilişsel olgunlaşma ve yaşantı çeşitliliği arasındaki ilişkinin, bilişsel gelişimi sağladığı bilinmektedir (Senemoğlu, 2012).

Bulguların genel bir değerlendirmesi yapıldığında, araştırmadan öncelikli olarak birkaç sonuç çıkarılabilir. İlk olarak, kanıt kullanımının öğrencilerin tarihsel düşünmelerini olumlu yönde etkilediği düşünülmektedir. Bu bağlamda tarihsel anlatılardan, birçok kaynağın tarihsel yorumları temellendirmek için kullanıldığı çıkarılmaktadır. Böylece öğrenciler, kanıt ve iddia arasındaki farkı ayırt edebilmiş ve tarihsel gerçek ile yorumu, kanıtlara dayalı olarak değerlendirebilmişlerdir. Sonuç olarak da kanıt kullanımının, tarihsel anlama ve yoruma olumlu etkileri olmuştur. Benzer şekilde birçok araştırmada, kanıtların bu etkileri sağladığı rapor edilmiştir (Ayva, 2012; Bozkurt, 2018; Işık, 2011; Patterson, Lucas ve Kithinji, 2012; Torres, 2016). İkinci olarak, kanıtların öğrencilerde farklı duygusal tepkilere neden olabileceği düşünülmektedir. Bu bağlamda aynı kanttları inceleyen öğrenciler, tarihsel temsilcilere yönelik, empatik ya da sempatik tepki verme eğiliminde olmuşlardır. Ancak sempati, Blake'e göre (1998), kişinin, empati yapmasında bir engel oluşturmaktadır. Üçüncü olarak, birincil elden kaynak kullanımı, öğrencilerin tarihsel sorgulamalarına katkıda bulunmuştur. Benzer şekilde Levstik ve Barton (2011), birincil elden kaynakların, tarihsel olayları anlamada en etkili sorgulama araçlarından biri olduğunu ve öğrenmeye yardım ettiğini ifade etmişlerdir. Buna paralel olarak birincil elden kaynaklar, tarihsel sorgulamayla ilgili öğrencilerin, uygulama becerilerini desteklemektedir (NCSS, 2013). Dördüncü olarak, öğrencilerin, kanıt ve kaynakları, anlatılarını desteklemek ve diğer görüşleri çürütmek amacıyla kullandıkları düşünülmektedir. Bu durum, öğrencilerin, tarihsel bilgiyi örgütlediklerine (Anderson ve Krathwohl, 2001) işaret etmektedir. Beşinci olarak, ortaya çıkan bulgular arasında, tarih öğretimine faydası bakımından en tartışmalı olanının 'özdeşleşme' olduğu düşünülmektedir.

\section{5. Öneriler}

Bulgulara dayalı olarak;

1- T.C. İnkılap Tarihi ve Atatürkçülük dersinde kanıt ve kaynakların, çok çeşitli bakış açılarını içerebilecek bir şekilde seçilmesi ve daha sonra derslerde kullanılması,

2- T.C. İnkılap Tarihi ve Atatürkçülük ders kitabında kanıt ve kaynak analizini gerektiren soruların yer almas1,

3- Sosyal bilgiler öğretmenlerine, tarih öğretimine uygun olarak, kanıt ve kaynakların nasıl işe koşulabileceğine yönelik seminerlerin verilmesi,

4- Sosyal bilgilerin tarih konularında, kanıt ve kaynak kullanımının, tarihsel anlatılara yansımalarına yönelik çalışmaların yapılması,

5- Diğer sınıf düzeylerinde de, kanıt ve kaynak kullanımının tarihsel anlatılara yansımalarına yönelik çalışmaların yapılması,

6- Kanıt ve kaynak kullanımının, tarihsel anlatılara yansımalarının, nicel veri toplama araçlarıyla da ortaya çıkarılması,

7- Kanıt ve kaynaklara dayalı olarak, öğrenci anlatı seviyelerinin nasıl arttırılabileceğinin araştırılması, önerilebilir.

\section{KAYNAKÇA}

Amaral, C. (2008). Tarih derslerinde farklı perspektifler: Portekizli öğrenciler ile bir çalışma. Bulunduğu eser: Safran, M. ve Dilek, D. (2008) 21. yüzyılda kimlik, vatandaşlık ve Tarih eğitimi. İstanbul: Yeni İnsan Yayınevi. s:163-174. 
Akbaba, B. (2005). Tarih öğretiminde fotoğraf kullanımı. Gazi Üniversitesi Kırşehir Eğitim Fakültesi Dergisi, 6, (1), 185-197.

Anderson, L.W. (Ed.), Krathwohl, D.R. (Ed.), Airasian, P.W., Cruikshank, K.A., Mayer, R.E., Pintrich, P.R., Raths, J., \& Wittrock, M.C. (2001). A taxonomy for learning, teaching, and assessing: Arevision of Bloom's taxonomy of educational objectives (complete edition). New York: Longman.

Ayva, Ö. (2012). Developing students' ability to read, understand and analyse scientific data through the use of worksheets that focus on studying historical documents. Procedia-Social and Behavioral Sciences 46, 5128-5132.

Bakmaz, H. (2016). Sosyal Bilgiler dersinde para ve pulların kullanımının öğrencilerin akademik başarısına etkisi. Yayımlanmamış Yüksek Lisans Tezi, Adıyaman Üniversitesi Sosyal Bilimler Enstitüsü.

Barton, K. C., \& Levstik, L. S. (2004). Teaching history for the common good. Mahwah, NJ: Lawrence Erlbaum Associates.

Bilgiç, S. (2018). Illkokul 4. sınıf Sosyal Bilgiler derslerinde kanıt temelli öğrenmeye ilişkin bir eylem araştırması. Yayımlanmamış Yüksek Lisans Tezi, Sakarya Üniversitesi, Eğitim Bilimleri Enstitüsü.

Blake, C. (1998). Historical empathy: A response to Foster and Yeager. International Journal of Social Education, 13(1), 25-31.

Bogdan, R.C., \& Biklen, S.K. (2007). Qualitative research for education: An introduction to theory and methods. 5th edition, Allyn \& Bacon, Boston.

Bozkurt, F. (2018). Sosyal Bilgiler öğretiminde kanıt temelli öğrenme uygulamaları. Akdeniz Ĕgitim Araştırmaları Dergisi, 12(24), 334-353.

Brooks, S. (2008). Displaying historical empathy: what impact can a writing assignment have?, Social Studies Research and Practice, 3 (2), 130-146.

Carr, E. H. (1996). Tarih nedir?. İstanbul: İletişim Yayınları.

Collingwood, R.G. (1996). Tarih tasarımı. Kurtuluş Dinçer (çev.). Gündoğan Yayıncılık, Ankara.

Cooper, H. (1996). "History 5-11", teaching History, (Ed. H. Bourd1llon), London: Routledge. s.7686.

Creswell, J. (2007). Qualitative inquiry \& research design: Choosing among five approaches (2nd ed.). USA: SAGE Publications.

Creswell, J. (2003). Research design: qualitative, quantitative, and mixed methods approaches (2nd ed.). Thousand Oaks, CA: Sage.

Creswell, J. (1994). Research design: Qualitative \& quantitative approaches. London: SAGE Publications.

Davey, L. (1991). The application of case study evaluations. Practical Assessment, Research \& Evaluation, 2(9).

De Leur, Boxtel C. V., \& Wilschut A. (2017). 'I saw angry people and broken statues': Historical empathy in secondary history education. British Journal of Educational Studies, 65:3, 331352. 
Dilek, D. (2009). Geçmişi imgelerle yeniden kurmak: İlköğretim düzeyinde tarihsel imgelem becerilerinin kullanımı üzerine ikonografik bir analiz. Kuram ve Uygulamada Ĕgitim Bilimleri, Bahar, 633-689.

Dillenburg, M. (2017). Understanding historical empathy in the classroom. Boston University, Dissertation.

Drake, F. D., \& Brown, S. D. (2003); “A systematic approach to improve students" historical thingking", The History Teacher, 36, (4), 465-589.

Endacott, J. L. (2013). Reconsidering affective engagement in historical empathy. Theory and Research in Social Education, 38(1), 6-49.

Foster, S. (2001). Historical empathy in theory and practice: Some final thoughts. In O. Davis, E. A. Yeager, \& S. J. Foster (Eds.) Historical empathy and perspective taking in the Social Studies (pp. 167-182). New York, NY: Rowman and Littlefield.

Glesne, C. (2015). Nitel araştırmaya giriş. Çeviri Editörleri: Ali Ersoy, Pelin Yalçınoğlu. 5. Baskı, Anı Yayıncılık, Ankara.

Grim, V., Pace, D., \& Shopkow, L. (2004). Learning to use evidence in the study of History. New Directions for Teaching and Learning, 98, 57-65.

Harris, R., \& Foreman-Peck, L. (2004). 'Stepping into other people's shoes: teaching and assessing empathy in the Secondary History Curriculum'. International Journal of Historical Learning, Teaching and Research, 4 (2), 1-14.

Hatch, J. A. (2002). Doing qualitative research in education settings. Albany: State University of New York Press.

Husbands, C. (1996). What is history teaching? Bristol, PA: Open University Press.

Işık, H. (2011). Ortaöğretim Tarih derslerinde birincil ve ikincil el kaynaklar ile etkinlik temelli ders işlemenin öğrencilerin tarihsel düşünme becerilerine etkisi. Turkish Studies-International Periodical For The Languages, literature and History of Turkish or Turkic, 6 (1), 13231337.

Jenkins, K. (1997). Tarihi Yeniden Düşünmek. Bahadır Sina Şener (çev.). 1. Baskı, Dost Kitabevi Yayın1, Ankara.

Kabapınar, Y. (2014). Kuramdan uygulamaya Sosyal Bilgiler ögrretimi (4. Baskı). Ankara: Pegem A Yayıncilik.

Keleş, H., Ata, B., Köksal, İ. (2006). Tarihi dokümanla Tarih öğretiminin lise öğrencilerinin başarısına etkisi. Gazi Eğitim Fakültesi Dergisi, 2, 99-112.

Kızıl, Ö. (2018). Sosyal Bilgiler dersinde tarihsel kanıt analizi kullanımının 7. sınıf öğrencilerinin akademik başarıları üzerindeki etkisi, International Journal of Eurasian Education and Culture, 4, 57-73.

Kiriş, A. (2009). Tarih eğitimi ve tarihçilik mesleği: Lise Tarih derslerinde öğrencilerin yazma becerilerini kullanması ve geliştirilmesi. Yayımlanmamış Doktora Tezi, Gazi Üniversitesi Eğitim Bilimleri Enstitüsü, Ankara.

Köksal, H. (2005). Tarih öğretiminde eleştirel düşünme becerilerinin geliştirilmesi, Yayımlanmamış Doktora Tezi, Gazi Üniversitesi, Eğitim Bilimleri Enstitüsü, Ortaöğretim Sosyal Alanlar Anabilim Dalı, Tarih Öğretmenliği Bilim Dalı, Ankara. 
Lincoln, Y. S., \& Guba, E. G. (1985). Naturalistic inquiry. Newbury Park, CA: Sage Publications.

Linda, S. L., \& Barton, K. C. (2011). Doing History: Investigating with children in elementary and middle schools, 4th ed. (New York: Routledge), 12-18.

Maxwell, J.A. (2005). Qualitative research design: An interactive approach (2nd ed.). Newbury Park, CA: Sage.

Milli Eğitim Bakanlığı (MEB). (2018). Türkiye Cumhuriyeti İnklap Tarihi ve Atatürkçülük dersi 8. sınıf programı. MEB, Talim Terbiye Kurulu Başkanlı̆̆ 1 , Ankara.

Merriam, S., B. (2009). Qualitative research. A guide to design and implementation, (2nd ed.) San Francisco, CA: Jossey-Bass.

Merriam, S. B. (1998). Qualitative research and case study applications in education. San Francisco: Jossey-Bass Publishers.

Miles, M. B., \& Huberman, A. M. (1994). Qualitative data analysis: A sourcebook of new method (2nd ed.). Thousand Oaks, CA: Sage.

Mims, J. L. (2002). Teaching with documents, how high school students make meaning from slave trials, letters and songs, Department of Instruction and Teacher Education, College of Education, University of South Carolina, Ph.D Thesis, USA South Carolina.

Monte-Sano, C. B. (2006). Learning to use evidence in historical writing. ProQuest Digital Dissertations Database. (UMI No. AAT 3235298).

Namal, R. (2011). İlköğretim 7.sınıf Sosyal Bilgiler dersinde yer alan "Ülkemizde Nüfus” ünitesinin ögretiminde görsel materyallerden yararlanmanın ögrenci başarısı üzerine etkisi. Yayımlanmamış Yüksek Lisans Tezi, Atatürk Üniversitesi, Eğitim Bilimleri Enstitüsü, Sosyal Bilgiler Eğitimi Ana Bilim Dalı, Erzurum.

Nation Consil for Social Studies (NCSS). (2013). Social Studies for the next generation: Purposes, practices, and implications of the college, career, and civic life (C3) framework for Social Studies state standards (Bulletin 113, Silver Spring, MD: NCSS), xvii.

Özbaş, B. Ç. (2010). 12 - 14 yaş grubu öğrencilerinin tarihsel düşünme gelişimi ve tarihsel kanıt kullanımı. Yayımlanmamış yüksek lisans tezi, Dokuz Eylül Üniversitesi, Eğitim Bilimleri Enstitüsü, İzmir.

Patterson, N. C., Lucas, A. G.\& Kithinji, M. (2012). Higher order thinking in Social Studies: An analysis of primary source document use, Social Studies Research and Practice,7(2),68-85.

Paivio, A. (1991a). Images in mind. New York: Harvester Wheatsheaf.

Paivio, A. (1991b). Dual coding theory: Retrospect and current status. Canadian Journal of Psychology, 45(3), 255-287.

Roord, L. J.(2009). Katılım, farkındalık ve hoşgörü için eğitim: Anahtar temaların Tarih eğitimiyle ilgisi ve önemi, Çok Kültürlü Avrupa İçin Tarih ve Sosyal Bilgiler Eğitimi, Harf Eğitim Yayıncılığı http://csd.erciyes.edu.tr/materyaller/tn_02.pdf.

Ruby, P., \& Decety, J. (2004). How would you feel versus how do you think she would feel? A neuroimaging study of perspective-taking with social emotions, Journal of Cognitive Neuroscience, 16 (6), 988-999.

Sander, O. (2013). Siyasi Tarih (İlkçağlardan 1918'e), 26. Baskı, İmge Kitabevi Yayını, Ankara. 
Seidel, J., \& Kelle, U. (1995). Different functions of coding in the analysis of textual data. In U. Kelle (Ed.), Computer-aided qualitative data analysis: Theory, methods, and practice (pp. 52-61). Newbury Park, CA: Sage.

Senemoğlu, N. (2012). Gelişim, ögrenme ve öğretim, 22. Baskı, Pegem Akademi Yayıncılık, Ankara.

Shemilt, D. (2000). The caliph's coin: The currency of narrative frameworks in history teaching. In P. N. Stearns, P. Seixas, \& S. Wineburg (Eds.), Knowing, teaching, and learning history: National and international perspectives (pp. 83-101). New York: New York University Press.

Silverman, D. (1993). Interpreting qualitative data: Methods for analyzing talk, text, and interaction. London \& Thousand Oaks, CA: SAGE.

Stradling, R. (2003). 20. yüzyıl Avrupa Tarihi nasıl öğretilmeli, Tarih Vakfı Yurt Yayınları, İstanbul.

Stake, R. E. (1995). The art of case study research, Sage Publications, Thousand Oaks, California.

Tangülü, Z. ve Çıdaçı, T. (2016). Sosyal Bilgiler Dersi Tarih konularının öğretiminde birinci elden kaynakların kullanımı. Sosyal Bilimler Dergisi, 6 (11), 253-273.

Tangülü, Z., Tosun, A. ve Kocabıyık, B. (2014). Ortaokul 8. sınıf İnkılap Tarihi ve Atatürkçülük konularının öğretiminde karşılaşılan sorunların sosyal bilgiler öğretmen görüşlerine göre değerlendirilmesi. Trakya Üniversitesi Sosyal Bilimler Dergisi, 16 (2), 233-245.

Torres, H. J. (2016). Hoovervilles, jalopies, and riding the rails: Investigating the great depression through primary sources. Social Studies and the Young Learner, 29 (1), 4-8.

Wineburg, S. (2001). Historical thinking and other unnatural acts. Philadelphia, PA: Temple University Press.

VanSledright, B., \& Frankes, L. (2000). Concept and strategic knowledge development in historical study: A comparative exploration in two fourth-grade classrooms. Cognition and Instruction, 18 (2), 239-283.

Vella, Y. (2009). In Search of meaningful History teaching. History teachers.' Association Publication. Malta.

Yahşi. İ. ve Keleş, H. (2013). "Tarih öğretiminde gazete kullanımının çok perspektifliğe etkisi." Kastamonu Eğitim Dergisi, 21 (2), 693-710.

Yeager, E. A., Foster, S. J., Maley, S. D., Anderson, T., \& Morris, J. W., III. (1998). Why people in the past acted as they did: An exploratory study in historical empathy. International Journal of Social Education, 13(1), 8-24.

Yıldırım, A., ve Şimşek, H. (2016). Sosyal bilimlerde nitel araştırma yöntemleri (10. b.). Ankara: Anı Yayınları.

Yin, R. K. (2003). Case study research: Design and methods (3rd ed.). Thousand Oaks, CA: Sage.

Yin, R. K. (1989). Case study research: Design and methods. Beverly Hills, CA: Sage. 